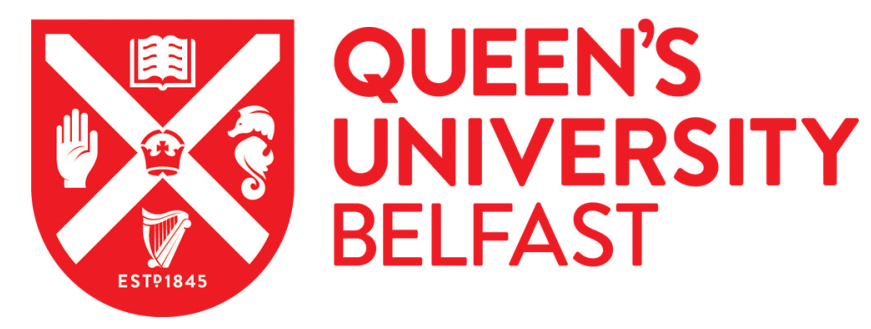

\title{
Dispelling the Myth of the Naive Investor during the British Railway Mania, 1845-46
}

Campbell, G., \& Turner, J. D. (2012). Dispelling the Myth of the Naive Investor during the British Railway Mania, 1845-46. Business History Review, 86(1), 3-41. https://doi.org/10.1017/S0007680512000025

\author{
Published in: \\ Business History Review
}

Document Version:

Peer reviewed version

Queen's University Belfast - Research Portal:

Link to publication record in Queen's University Belfast Research Portal

Publisher rights

(c) The President and Fellows of Harvard College 2012.

\section{General rights}

Copyright for the publications made accessible via the Queen's University Belfast Research Portal is retained by the author(s) and / or other copyright owners and it is a condition of accessing these publications that users recognise and abide by the legal requirements associated with these rights.

Take down policy

The Research Portal is Queen's institutional repository that provides access to Queen's research output. Every effort has been made to ensure that content in the Research Portal does not infringe any person's rights, or applicable UK laws. If you discover content in the Research Portal that you believe breaches copyright or violates any law, please contact openaccess@qub.ac.uk. 


\title{
Dispelling the Myth of the Naive Investor during the British Railway Mania, 1845-46 \\ Gareth Campbell and John D. Turner
}

\begin{abstract}
Anecdotal evidence from the British Railway Mania and other historical financial bubbles suggests that many investors during such episodes are naive, thus contributing to the asset price boom. Using extensive investor records, we find that very few investors during the Railway Mania can be categorized as such. Some interpretations of the Mania suggest that naive investors were expropriated by railway insiders, but our evidence is inconsistent with this view as railway insiders contributed substantial amounts of capital, and their investments performed no better than those made by other experienced investors.
\end{abstract}

\section{Published}

Campbell, G \& Turner, JD 2012, 'Dispelling the Myth of the Naive Investor during the British Railway Mania, 1845-46' Business History Review, vol 86, no. 1, pp. 3-41., 10.1017/S0007680512000025 (http://dx.doi.org/10.1017/S0007680512000025) 
Who invests during asset price bubbles? Anecdotal evidence from historical bubbles suggests that investors during such episodes are inexperienced, amateurish, naive, and even impecunious. ${ }^{1}$ However, there have been few academic studies on the characteristics of investors during such periods. ${ }^{2}$ In this paper, we examine the naivety and possible expropriation of investors during the British Railway Mania of the mid1840s. According to Charles Mackay, writing in the 1856 edition of his book, this episode was at the time the greatest example of a financial mania in history, a view which, despite several prominent bubble-like episodes since, is still held today. ${ }^{3}$ The Railway Mania is regarded as such because of the more than one thousand railway companies that were established in 1844-46 accompanied by a substantial reversal of railway stock prices.

The anecdotal evidence regarding investor characteristics during the Railway Mania is similar to that for other bubble-like episodes. William Makepeace Thackeray's satirical poem The Speculators, as well as the satirical press from the time, suggests that the naive and impecunious were heavily involved as investors during the Mania. ${ }^{4}$ Others allude to the participation of inexperienced investors such as widows and clergymen, and the large role played by the middle class, with the implication being that they were amateur investors who lost heavily. ${ }^{5}$ Indeed, it is even suggested that the clamor for railway shares by naive and inexperienced investors contributed to the creation of the Railway Mania itself. ${ }^{6}$ Some commentators have suggested that asset price bubbles are part of an attempt by insiders to expropriate these amateur investors. ${ }^{7}$ This would imply that during such an episode, both experienced insiders and inexperienced outsiders participate in stock trading, but high returns are earned by the former at the expense of the latter. This paper investigates these issues by addressing two main questions. First, how much knowledge and experience did investors have during the Mania? Second, how did investments made by different types of investors perform?

We use four measures of investor knowledge and experience. Firstly, the occupation of investors is used as a proxy for their knowledge of business and the political process. Secondly, past investment activity is used as a measure of their experience with the stock market. Thirdly, as railways were focused in particular geographical districts, we consider whether investors had knowledge of the locality. 
Fourthly, we examine railway insiders, who were either directors of established railways, or who were on the provisional committees of the projected railways.

Our main data sources are the lists of individuals who subscribed to new railway companies, and shareholder lists of one of the established railways, the Great Western Railway. Both of these sources provide information on the occupation and location of investors. We also use contemporaneous shareholder lists from the banking sector to ascertain the extent to which railway investors were novices. Finally, we use stock price data to determine whether or not certain investor characteristics were correlated with first-day investment returns and long-run success.

We find that experienced investors contributed a large proportion of capital. Businesspeople, investors with previous investment experience, investors from the railway's locality, railway directors and provisional committee members were all active in providing capital. In terms of investment performance, our evidence suggests that businesspeople and investors from the railway's locality invested in projects which had higher returns, whereas inexperienced investors tended to invest in projects which provided lower returns. Investments made by railway insiders did not perform as well as those made by other experienced groups, which may partially absolve them of acting in an opportunistic way during the Mania.

One of the broader implications of this paper is that the role played by inexperienced investors during asset price booms may not be substantial. This implies that we have to look elsewhere for the causes of asset price booms, and we cannot dismiss such periods as simply being the product of irrationality and naivety. Our findings also imply that bubbles are not necessarily an attempt by insiders to expropriate others. The biggest winners during the Railway Mania were those with experience, rather than inside knowledge, and attempts to hold insiders culpable for the development of a bubble may be misplaced.

As well as adding to our knowledge of investors during asset price booms, this paper augments the growing literature on investor characteristics in the Victorian equity market. $^{8} \quad$ Although we know quite a lot about bank investors across the nineteenth century, our knowledge of railway investors is largely confined to the pre-Mania period. ${ }^{9}$ 
The Railway Mania and the Primary Market for Railway Shares

The first modern passenger railway in Britain, the Liverpool and Manchester railway, opened in 1830. Following its success, new railway companies were promoted during the mid-1830s, with Parliament authorizing fifty-nine new railways, having about $£ 36.4$ million of capital. ${ }^{10}$ After this flurry of activity, railway promotion was effectively dormant until 1843. In 1843, there were sixty-three applications to Parliament, followed by 199 applications in 1844, and by the end of 1845 there were another 562 applications. ${ }^{11}$ In addition, there were many projected companies that did not even reach the point of applying to Parliament, with The Times estimating that there were 1,263 new projects in $1845 .^{12}$

This boom in promotional activity was accompanied by a substantial run-up and collapse of railway stocks. As can be seen from Panel A of Figure 1, the index of railway stocks peaked at 1,984 on 8 August 1845, and stayed close to that level for two months (all figures and tables can be found in the appendix at the end of the article). It then fell to 1,623 by the end of November 1845, and reached a low of 673 on 19 April 1850. As shown in Panel B of Figure 1, the returns to established railways (i.e., railways that had been operating before 1843) and the returns to new railway companies excluding the first day that the share was traded on the market, are similar. The greatest gains went to those who had subscribed for shares when the company was first being promoted, before it obtained a stock market listing, as shares often rose to a premium as soon as they were listed on the secondary market. The compound effect of subscribing to all new companies which eventually obtained a stock market listing is shown in Panel B of Figure 1.

If a group of individuals wanted to set up a railway company, they had to deposit a detailed application for a railway Bill with parliament in the November prior to the parliamentary session. Part of the parliamentary submission included a subscription contract, containing the names, addresses, and occupational details of shareholders who had paid up 10 percent, and who had jointly undertaken to provide 75 percent of the company's capital. $^{13}$

To attract investors, promoters would issue a prospectus, usually in the press, and invite applications to be made. ${ }^{14}$ These prospectuses generally contained details regarding the amount of capital being raised, the deposit required, members of the 
provisional committee, the proposed route, the advantages of the scheme, and lists of stockbroker offices where applications for shares could be made. ${ }^{15}$

Applicants in the 1840 s usually had to provide a reference as to their standing along with their application. ${ }^{16}$ If an application was successful, shares were then allotted (or allotted on a pro rata basis in the case of oversubscription) to applicants. At this point, they had to pay the 10 percent deposit on the shares, and in return they received a scrip certificate - this entitled the bearer to a stipulated number of shares if the company successfully obtained a Bill and was incorporated. The original allottees were liable for all future calls should the company be successfully incorporated, and before that time, they were liable unlimitedly for all debts incurred by the company. ${ }^{17}$

Although scrip certificates could not be legally traded, an active market arose for railway scrip because certificates were made out to bearer and could therefore be easily transferred without fear of legal penalty. ${ }^{18}$ However, original holders of scrip may have been reluctant to sell their scrip as they remained legally liable for all debts of the company until it was incorporated. ${ }^{19}$ In addition, the buyers of scrip were in a dubious legal position if they wanted to recover losses from the promoters. ${ }^{20}$

\section{Data on Investors during the Mania}

One of the key features of the Mania was the promotion of over one thousand new railway lines, so the examination of who subscribed the initial capital for such projects can give a particularly useful insight into who made the promotion boom possible. The absence of most extant shareholder lists and share registers also means that subscription contracts are one of the only sources of information we have on who invested during the Mania. $^{21}$ Indeed, in the case of the Railway Mania, it has been suggested that subscription contracts may provide a greater insight than shareholder records into the "fever of speculation which gripped the middle classes in 1845."22

One potential weakness with subscription lists is that the majority of subscribers could have quickly sold their scrip or shares to others during the Mania, and it is really these buyers who we should be interested in if we want to understand who invested during the Mania. ${ }^{23}$ However, it was well known at the time that those who made the largest profit during the Mania were subscribers rather than those who purchased shares 
on the secondary market. ${ }^{24}$ In addition, railway directors, who essentially allotted shares, may have had a preference for permanent investors rather than temporary speculators. ${ }^{25}$

In April 1845, Parliament printed an alphabetical list of subscribers to railway schemes along with their description, addresses, railways they had invested in, and the amount of capital they had subscribed. ${ }^{26}$ This list is 539 pages long, and contains all the subscribers to 209 railway contracts that had been deposited in the year before November 1844. Similarly, in April 1846, Parliament printed a list of all persons who had subscribed $£ 2,000$ or more to any railway subscription that had been deposited in the year before November $1845 .^{27}$ This list is 320 pages long and contains subscribers of $£ 2,000$ or more to 556 railways. In other words, between the two subscription lists, we can identify all those who subscribed to new railway ventures in the run-up phase of the Mania, and all large subscribers who invested whenever the Mania was close to or at its peak.

The two parliamentary lists of railway subscribers were criticized at the time because it was alleged that they contained fictitious characters, placed there by the promoters to increase the respectability of the subscription list, and impecunious stags who applied for shares in new railways using false addresses. ${ }^{28}$ However, periodicals at the time did not question their authenticity. ${ }^{29}$ More importantly, a parliamentary report into the subscription list of the London and York Railway found that out of 1,101 subscribers, only four were fictitious in that the subscriber had given a false address, name or socio-occupational description. ${ }^{30}$ The parliamentary committee's conclusion was that the petitioner (a vice-chairman of a rival railway) was vexatious, and was simply interested in hindering the progress of the London and York railway through parliament. ${ }^{31}$ Notably, the aspersions he cast resulted in the London and York railway not being authorized by Parliament. ${ }^{32}$ Consequently, one would assume that subscription lists (particularly companies authorized by Parliament) did not contain too many fictitious or fraudulent individuals as such weaknesses could be used by opponents to prevent a railway company being authorized by Parliament. ${ }^{33}$

It is highly unlikely that nominees were numerous in the subscription lists as it was a costly and sophisticated legal device out of the reach of most individuals. ${ }^{34}$ For 
example, the inquiry into the subscription list of the London and York railway suggests that only five subscribers out of 1,101 may have been nominees. ${ }^{35}$

A further potential problem with subscription lists as an information source is that they may reveal more about the preferences of promoters for a reputable as well as local shareholder body rather than the preferences of investors per se. ${ }^{36}$ Although there is not much evidence of favoritism on the part of promoters, they may have wanted to ensure a reputable and local shareholder body so as to convince parliamentarians of the merits of their proposal. ${ }^{37}$ This may explain why subscribers had to provide their sociooccupational status as well as a reference when applying for railway shares. ${ }^{38}$ However, the providing of references became little more than a matter of form during the Mania. ${ }^{39}$ In addition, such was the number of railway schemes before Parliament that close scrutiny of subscriber lists would have been very costly. Indeed, it has been observed that the success of schemes had more to do with luck rather than anything intrinsic about the scheme or the list of subscribers. ${ }^{40}$

\section{Business and Political Experience}

To assess whether investors were experienced in business, or had superior knowledge of the Parliamentary authorization process for railway schemes, we examine the occupations of investors, using the description given in the Parliamentary subscription lists. We acknowledge that occupational status may be a blunt tool for determining experience as some women investors or others we classify as being inexperienced may have been very knowledgeable, and some individual businesspeople or railway directors may have had little business understanding as such. However, on average, we believe that occupational categories are reasonably good indicators of experience, and contend that it is useful to place investors on a spectrum with regards to their experience of business and politics based on their occupation. ${ }^{41}$

Although an individual may have exaggerated their status, it was in the selfinterest of railways to ensure that it was accurately reported. A small proportion of investors do not have an occupational description, and in the very small number of cases where there is joint ownership, the occupation of the first-named investor was recorded. Many of the occupational categories are self-explanatory, but several occupations were 
grouped into broader categories. ${ }^{42}$ Many investors were described as gentlemen or esquires in the Parliamentary lists; these were mainly unoccupied men living off rental income. Although these titles may have been courtesy ones, it is unlikely that unoccupied men who were not from this social class were automatically labeled as such: the inclusion of investors in the lists with no description would suggest that this was not the case. ${ }^{43}$ Women investors who reported an occupation or a noble social status were assigned to the relevant socio-occupational category. Other women investors were selfreported in the subscription lists as either widows or spinsters. These self-designations tell us little about their social status, but they may indicate that these individuals were excluded from others means of financial support.

Table 1 breaks down all subscribers in the 1845 and 1846 Parliamentary lists by occupation; the two lists are not directly comparable as the 1846 list only contains those who subscribed more than $£ 2,000$. Table 1 reveals that clergymen and women, the stereotypical naive or inexperienced investors, make up a very small proportion of investors and contributed just 1.2 percent of capital during the Mania. In terms of naive, low-wealth investors, the skilled and unskilled working classes constitute less than one percent of investors and about 0.1 percent of total capital pledged during the Mania. The non-business middle classes (i.e., professionals and white-collar investors), who were perceived by some as amateur investors, only constitute about 10 percent of investors, and contributed about 6 percent of capital.

The experience of gentlemen, and members of the armed forces and nobility is somewhat debatable. They might have lacked dedicated business experience, but they may have had knowledge of managing their finances, and often would have been directors of companies. They were a major contributor of capital, providing 34.3 percent of total capital.

Those with most experience of business would have been those involved in commerce and finance. Merchants made up 21.7 percent of investors, and provided 30.7 percent of capital in total. Manufacturers and retailers contributed a further 8.2 percent of capital. Although the financial interest constituted a relatively small proportion of investors, they contributed about 7.8 percent of capital during the Mania. This suggests 
that individuals with considerable experience of practical business were keen to invest in new railway schemes.

Given the obstacles that new railway projects needed to overcome to obtain Parliamentary authorization, it is also possible that investors with legal and political experience could be regarded as having relevant knowledge and experience. In addition, solicitors often handled the business and financial affairs of clients. Table 1 reveals that legal professionals contributed a sizable proportion of capital (7.8 percent). Although legal professionals have been traditionally castigated for their part in the Mania in terms of their involvement in railway promotions, it appears that they were significant investors. ${ }^{44}$ Politicians, given their small population, are also well represented among railway investors during the Mania, with about one-quarter of all MPs investing in railway shares. As well as having knowledge of particular schemes, MPs might have had an incentive to influence the fortune of particular schemes through Parliament. However, their ability to do so may have been limited by the fact that the committees who made the decisions on individual railway companies were to be composed of five members, each of whom had to sign a declaration that their constituents as well as they themselves had no personal interest in the railway.

From Table 2, which examines those individuals who appear on the 1845 and 1846 subscription lists as well as the top percentile of investors during the Mania, we can see that of the 12,549 individuals who invested near the peak of the Mania, only 3,248 of those had invested in the run-up phase. However, these 3,248 individuals invested 46.6 percent of the total capital during the Mania, averaging 5.7 investments in separate companies. In other words, those individuals who invested in both phases of the Mania do not appear to be naive or inexperienced investors; rather they are major providers of risk capital. Indeed, during the Mania, the majority of subscribed capital was concentrated in the top percentiles of the distribution. For example, the top four percentiles of shareholders provided half the capital. The occupational status of the top percentile, who provided 31.3 percent of capital, can be seen from Table 2: 125 merchants and 106 gentlemen alone subscribed 21.7 percent of the total capital during the Mania. 
Taken as a whole, the view of the Mania that sees the bulk of capital being provided by many small naive investors is one that this evidence clearly contradicts. The most inexperienced groups of investors provided little capital, the upper classes who may have some experience contributed much more, whilst those experienced in business and finance provided the majority of capital.

\section{Prior Investment Experience}

Even if individuals were not directly involved in business, they may have had experience of investing in other stocks. Historical asset price booms have usually been associated with "individuals with little or no experience of the stock market investing for the first time." ${ }^{45}$ With respect to the Railway Mania, it is traditionally believed that many individuals had never invested in equities before. ${ }^{46}$ To what extent were Mania investors novices to equity investment? To answer this question, we use other contemporaneous shareholder lists.

At the time of the Mania, there were many other companies whose shares traded on public markets. For example, apart from railways, in 1845 there were just over 150 equity securities traded on the London Stock Exchange, and stocks of 148 banks traded on the London and the regional stock exchanges. ${ }^{47}$ Fortunately, we have a list of all shareholders in Scottish banks in $1845 .^{48}$ This list contains the name, description, and address of about 14,000 shareholders who held shares in the nineteen joint-stock banks in existence at that time; the vast majority of these shareholders (97 percent) lived in Scotland.

To ascertain whether Mania investors were novices, we match all railway investors from Scotland with the list of Scottish bank shareholders. The process of matching these two lists required that an individual have the same name, description, and address in both lists. This approach results in a potentially large underestimation of the number of railway subscribers who were also bank shareholders because occupations in one list may have been specific whereas in the other they were generic; individuals with commonly-occurring surnames and descriptions (i.e., merchant or gentleman) whose address was just reported as Edinburgh or Glasgow have been excluded as we cannot determine whether or not they were the same individual; it may have been commonplace 
for businesspeople to give their business address in the list of bank shareholders and their home address in the subscription lists.

Given the above underestimation problems, it is notable that 30.6 percent of railway subscribers who lived in Scotland were also holders of Scottish bank shares, and these individuals contributed 43.9 percent of total railway capital subscribed by Scottish investors. The severity of the underestimation problem is illustrated by the fact that only 45.2 percent of bankers who subscribed to railways held bank shares. This is an extremely unlikely scenario as bankers typically held shares in their own banks.

We also obtained shareholder records for the Sheffield and Hallamshire Banking Company, which enabled us to determine who had invested in its shares in the period from its inception in 1836 to 1845 . $^{49}$ This bank was one of three banks in Sheffield at the time, and was similar to other Sheffield banks in that there were very close links between it and industry, with the result that the Sheffield manufacturing and mercantile classes dominated the shareholding constituencies of these banks. ${ }^{50}$ Using the same matching approach as in the Scottish case above, we estimate how many individuals from Sheffield invested in railways and had invested in this bank between 1836 and 1845 . There were five hundred individuals from Sheffield who invested during the Mania, and ninety of these investors had invested in the shares of the Sheffield and Hallamshire bank. These ninety investors subscribed 24.4 percent of railway capital in Sheffield. These are remarkably high figures given that there were two other joint-stock banks in Sheffield. ${ }^{51}$ In addition, shares in Sheffield banks were almost exclusively held by businesspeople, implying that a lot of non-business railway investors would have been excluded from holding them. ${ }^{52}$

We also ascertained which Great Western Railway (GWR) shareholders in 1843 went on to subscribe to new railways during the Mania. Our analysis suggests that 473 GWR shareholders (23.5 percent) went on to subscribe to new railways and these investors contributed 3.6 percent of capital during the Mania. As these investors would have had experience of how railways were constructed, financed, and operated, they cannot be regarded as naive or inexperienced. If a similar proportion of investors in other established railways went on to invest in new projects, the contribution of capital during the Mania by such individuals would have been substantial. 
Consideration of each of these sources of previous investment experience suggests that a substantial proportion of investors had invested in the equity market prior to the Mania. This implies that these investors would have been familiar with the risk and returns that were associated with stock market investments.

\section{Knowledge Based on Geography}

Prior to the Mania, the important sources of railway capital were the Northwest (primarily Lancashire), London, and Yorkshire. ${ }^{53}$ One would therefore expect that investors residing in these regions had extensive experience of railway investment prior to the Mania as they had actually witnessed the success of railways in their locality. As can be seen from Figure 2, the vast majority of investment during the Mania came from these three regions, with close to 60 percent of subscribed capital and over 50 percent of investors coming from these three regions.

London becomes a slightly more important source of railway capital during the Mania than it had done beforehand, with 20.7 percent of Mania investors living in London. ${ }^{54}$ This may suggest that the capital market had become a national one, with investors naively giving funds to companies of which they had little knowledge. However, somewhat countering this, London investors, on average, invested more in railways than investors from other regions, with the result that 29.9 percent of subscribed capital was from London. ${ }^{55}$ Indeed, close to one-third of the top percentile of investors are from London, and these 110 investors subscribed one-third of total capital during the Mania, implying that the London elite were heavily involved during the Mania and not just after the market had reached its nadir. ${ }^{56}$

Investors in local railways on the whole may have had more information than non-local investors. Although some local investors may have invested for reasons of local pride, peer pressure or because of positive externalities, this does not mean that they did not care about (or have information on) the future financial prospects of the railway they invested in. In order to measure the extent to which investors invested in railway projects in their local area, we ask whether or not an investor lived in the same county as one of the proposed railway's termini. ${ }^{57}$ Such investment is classified as local 
investment. Termini for each railway were determined from the railway's appellation and Carter's Historical Geography of the Railways.

A substantial number of shareholders invested in local companies during the Mania, with 34.7 percent of investments being made by shareholders living in the county of the railway's termini. This may suggest that many investors chose to invest in

companies about which they had superior local information. ${ }^{58}$ The regional disparities in local investment in are noteworthy; over 49 percent of investors in Southwest England, Northeast England, large parts of Scotland, and South Wales invested in railways in their region. In contrast, the majority of investors from London and the North-West did not invest in local railways, suggesting that the pattern established prior to the Mania of these two regions playing an important role in financing non-local railways continued during the Mania.

These results confirm that a substantial proportion of investment came from regions which were established providers of capital, whilst another major proportion was local in nature. Both of these findings lend to support the view that many investors were not inexperienced in that they had relevant geographical knowledge and experience.

\section{Railway Insiders}

It could be argued that the strongest form of knowledge and experience would be possessed by those who could be regarded as railway insiders i.e., directors of established railways and members of provisional committees. Although some insiders may have been delusional about the potential success of their railway scheme, on the whole this group would have had greater knowledge of schemes than other investors. As information on insiders was not reported in the Parliamentary subscription lists, we obtained the directors of established railways from the 1845 Railway Directory and provisional committee membership was obtained from advertisements for new schemes in the Railway Times. Although not every scheme in the Parliamentary subscription lists advertised in this periodical, we managed to find membership details for 196 schemes, covering 43.8 percent of investment in new railway schemes.

As can be seen from Table 3, provisional committee members were substantial investors in schemes which they promoted as well as other schemes. Provisional 
committee members provided 18.5 percent of total capital in the railway schemes which they helped promote and 32.4 percent of total capital in all railway schemes. On average, the investors in Table 4 were in 1.4 provisional committees and invested in 1.1 other railway schemes.

The majority of the 2,058 provisional committee members were merchants and manufacturers (36.0 percent) and gentlemen (31.7 percent). Legal professionals, bankers, and politicians were also well represented on provisional committees. Unsurprisingly, so-called inexperienced investors were not members of provisional committees, and members of the middle classes were not well represented either.

Directors of established railways, who mostly were either businessmen or gentlemen, were substantial investors in new railway schemes, with many of them being amongst the top percentile of investors during the Mania. Overall, directors of established railways contributed 15.3 percent of total capital during the Mania. In addition, close to one quarter of directors who invested during the Mania were also on the provisional committees of new schemes.

The above evidence suggests that a substantial proportion of funds for railway schemes during the Mania came from railway insiders, suggesting that a large proportion of investment came from individuals with extensive knowledge of the railway industry. In addition, the level of investments made by these insiders suggests that they did not act in an opportunistic fashion during the Mania as they had a major stake in the success of the new railway schemes.

\section{Investors and Investment Success}

In this section, we examine the relationship between investor characteristics and the performance of their investment in order to ascertain whether investor experience and insider knowledge translated into superior investment performance. We measure performance by the price/par ratio enjoyed by a railway security on the first day it is quoted on the market. ${ }^{59}$ This measures the gain to the original subscriber as many of the first-day prices were for scrip rather than shares. As can be seen from Figure 1, most of the return earned on new railway schemes was generated by its first-day return, suggesting that initial subscribers enjoyed the bulk of returns. Indeed, a contemporary 
investment expert highlighted the effect of first-day returns, suggesting that first-day returns of 100 percent were to be expected. ${ }^{60}$

We measure long-run success of an investment in a railway by using the price/par ratio on the last day for which a security is quoted. In essence, what we are attempting to measure with this variable is the success or otherwise of railway companies in the longer run. Our basic premise is that less successful schemes will have lower price/par ratios on the last day its shares trade. As the vast majority of railway companies established during the Mania were not independent companies by the end of the 1840s, this last price observation for most companies is the last price quoted before the company either merged with another company or leased its line to another company or was wound up. For the few companies that survived to 1850, we use the last price/par ratio of that year as a measure of long-run performance. Even though the original investor may have sold their stocks at this point, we are essentially asking whether or not they invested in a railway that proved to be successful in the longer run.

The price/par ratios were obtained from various issues of the Railway Times. We then regress the investor characteristics for each individual investment on the first and last day price/par ratio for each individual investment. We also control for the size of the investment, the fraction of capital called up, and the year the investment was made.

As can be seen from Table 4, investments made by women and those who we categorize as inexperienced perform less well than those made by other investors. In addition, investments made by the middle classes (professionals and white collar) and upper classes also perform less well than those made by other investors, but the coefficient on those variables is smaller than that on the women and inexperienced variables. ${ }^{61}$ Contrastingly, merchants, and the rest of the business class (manufacturers and retailers) made investments that performed better than those made by other investors, but investments made by investors from the finance sector perform no better or worse than those made by other investors.

There is some evidence of those with legal experience earning higher returns but, apart from specification 9 in Table 4, which is based on a smaller sample, investments made by politicians do not perform any better than those made by other investors. This would suggest that their knowledge of the authorization process did not necessarily 
bestow them with greater insider information. This finding would also appear to partially absolve MPs from claims that they acted in an opportunistic manner during the Mania. ${ }^{62}$

The positive and significant coefficient on the local variable in Table 4 implies that investments made by local investors performed better than those made by non-local investors, suggesting that the superior information of local investors enabled them to invest in better performing railway stocks. It also appears from Table 4 that large investors, proxied by the variable PortfolioValue, do not necessarily choose better performing investments. However, the coefficient on the PortfolioNum variable suggests that an investment made by an investor who has invested in multiple railway schemes has a higher price/par ratio on the first and last day of trading. This suggests that those who invested in multiple railway schemes had superior knowledge of what was a good investment.

As can be seen from Table 4, investments made by railway insiders (directors and chairmen of established railways as well as provisional committee members) had mixed success. Investments made by directors tended to earn higher returns, but those made by chairmen did not. Those made by provisional committee members actually performed no better or worse than those of others. Taken as a whole, this evidence suggests the following. First, provisional committee members did not act opportunistically and they did not necessarily have superior information than other investors. Second, established railway directors did not make relatively larger short-term gains from their investments than others investors. This is inconsistent with them being viewed as charlatans chasing short-term gain. ${ }^{63}$ An alternative explanation is that directors used their extensive knowledge of the industry to avoid investing in "bubble" companies that earned high first-day returns.

Table 5 reveals the extent to which investor characteristics correlate with the long-run success of a new railway scheme. On the whole, the results parallel those found in Table 4, with businesspeople being more likely than women and inexperienced investors to invest in railways which were more successful in the long run and local investors being more likely to invest in more successful railway schemes. However, two interesting results emerge from Table 5. First, provisional committee members were more likely to invest in railways which were less successful in the long run, which 
implies that they did not have superior information than other investors, and they may even have invested for reasons other than earning a financial return on their investment. Second, directors of the established railways were more likely to invest in railway schemes that were more successful in the long run, implying that they had superior information on the long-run success of new railway schemes.

\section{Established Railways}

The results in the previous section are interesting in so far as they allow us to examine the relative success of investors in choosing between assets. However, during an asset price reversal it is also important to consider the relative performance of investors in choosing when they enter and exit the market. To investigate this issue, we analyze the shareholder records of the Great Western Railway (GWR), a large railway that had been authorized by Parliament in 1835 to construct a line between London and Bristol.

This is the only company we were able to locate that had surviving records listing the identity of its shareholders at different points in time throughout the course of the Mania. It is also one of only a few railways which was not reorganized as a result of amalgamations, meaning the same classes of shares traded continuously during the period. Notably, as can be seen from Figure 1, the asset price reversal experienced by the GWR was similar to the market as a whole.

The three shareholder lists that we analyze are the holders of $£ 100$ and $£ 20$ shares from February 1843, 1845, and $1848 .{ }^{64}$ Although the GWR also had $£ 50$ shares in this period, the shareholder records for this class in 1845 have not survived. Nevertheless, the holders of $£ 100$ and $£ 20$ shares constituted the vast majority of the company's stockholders, and owned 72 percent of the company's equity capital in 1845 .

Table 6 reveals that the profile of investors in the GWR is broadly similar to that found in the subscription lists of new schemes. The business and upper classes are again the biggest contributors, with gentlemen being relatively more important. There were, however, a higher proportion of women investors in the GWR compared to the new railways, and this proportion increased slightly over the course of the Mania. However, these findings do not imply that GWR investors were inexperienced; it more likely reflects the fact that this railway was paying a dividend of eight percent in 1845, which 
made it attractive to male and female rentiers. ${ }^{65}$ Consistent with this finding, a contemporary investment guide recommended that those looking for immediate income should invest on the established lines, whereas those looking for long-term capital gains should focus on the new railways. ${ }^{66}$

The location of investors also follows a similar pattern to that of the new railways, with investors from London and Lancashire, and local investors from Gloucestershire, providing most of the capital.

There is also evidence of railway insiders holding shares in the GWR. Using the Railway Directory to identify directors, we found that as well as each of the GWR's fourteen directors holding shares in the company, directors of other railways also held GWR shares. The numbers of railway directors holding shares in the GWR were as follows: forty-seven in 1843, forty in 1845, and thirty-four in 1848 .

By analyzing which investors were present in each of the years, it is possible to determine during which period individuals entered and exited their investments in GWR shares. Using share price and dividend data, this information can be used to determine which investors gained and lost from their investments.

Indices of capital gains and total returns have been calculated to estimate the returns to GWR shareholders during the Railway Mania, as shown in Figure 1. The indices have a base of 1,000 in Feb. 1843. Share prices rose almost continuously thereafter so that at Feb. 1845, the total return index stood at 1,817. Within the space of a few months, GWR stock prices then began to fall continuously so that at Feb 1848 the total return index stood at 1,102, and by March 1848 it had fallen to 979 .

The Feb. 1843 premium on GWR shares was at an all-time high since trading began in 1835. This means that it was likely that someone who held shares in Feb. 1843 had paid less than the index level of 1,000. If they sold out prior to Feb. 1848 they had sold at a level above 1,000. Therefore, we define anyone holding shares in Feb. 1843 and who had sold by Feb. 1848 as a gainer. Conversely, anyone who did not hold shares in Feb. 1843 had to pay more than the index level of 1,000. If they sold out after Feb. 1848, they are very likely to have sold for less than a level of 1,000. Consequently, anyone not holding shares in Feb. 1843, but who were holding shares in Feb. 1848 is defined as a loser. We categorize those who were shareholders in both 1843 and 1848 as long-term 
investors, and those who held shares in only 1845 as flippers. We cannot say very much about the losses or gains of the latter, but the fact they flipped their shares may suggest that they were speculators.

From Table 7, we observe at least five things of note. First, there are many more losers than gainers, which is largely due to a large number of new shareholders purchasing GWR shares for the first time between 1845 and 1848. Second, there are a relatively low number of flippers, perhaps suggesting that short-term speculators were in a minority. Third, although all types of investors are present in the loser category, there are proportionally more women and inexperienced investors in this group. Fourth, merchants and businesspeople are the two categories where there are more gainers than losers. Fifth, the same holds true for investors from Lancashire.

Table 8 contains the results of multinomial logit regressions where gainer is taken as the comparison or base group. In essence, the coefficients show whether a variable made it more or less likely that an investor was in a particular group other than the gainer group. More specifically they reveal the impact that a change in an independent variable will have on the log of the ratio of the probability of being in a particular group compared to the probability of being in the gainer group. For example, the 0.413 coefficient on the women dummy variable in column 2 of Table 8 can be calculated and interpreted as follows. After controlling for other factors, for a woman (when the dummy variable equals 1) the probability of losing is 0.506 , and the probability of gaining is 0.219 , therefore the ratio of losing to gaining is 2.307, and the $\log$ of this ratio is 0.836 . For a man (when the dummy variable equals 0 ) the probability of losing is 0.417 , and the probability of gaining is 0.273 , therefore the ratio of losing to gaining is 1.527 , and the $\log$ of this ratio is 0.423 . The impact of being a woman (when the dummy variable moves from zero to one) is calculated as the difference in the logs of the ratios, namely 0.836 minus 0.423 , which gives the coefficient value of 0.413 . The significance of the coefficient indicates that we can be confident in the result, namely that being a woman increases the probability of losing rather than gaining.

From Table 8, we see that women and inexperienced investors were more likely to be losers rather than gainers, whereas the reverse is true for merchants, the business classes, and the upper classes. Although the coefficients on the Director variable in 
specification two of Table 8 is negative on both occasions, only one coefficient is statistically significant, and it is only at the 10 percent level. This suggests that railway directors were no more likely to be losers rather than gainers. However, railway chairmen were significantly less likely to be losers, providing mixed results for the overall position of railway insiders.

From both panels of Table 8 we see that investors from Lancashire and local shareholders were more likely to be gainers rather than losers. This may suggest a level of investment astuteness on the part of shareholders from Lancashire and superior information on the part of local investors. We also see that GWR investors who also invested in one of the new railway schemes were more likely to be gainers rather than losers. This might be because such investors sold their GWR stake to invest in new railways or it could indicate that GWR investors who invested in new railways were more experienced investors.

\section{Conclusions}

The anecdotal evidence for the Railway Mania does not deviate from the stereotypical view that investors during asset price booms are inexperienced and naive. However, our findings suggest that it would be an error to suggest that the Mania was driven by such investors. Using a range of measures, we find evidence that many investors were highly experienced. Although we do not directly address the issue of whether the Railway Mania was a financial "bubble," our findings do not coalesce well with an interpretation of the Mania that argues that substantial investments by naive investors contributed to the asset price boom and bust.

One potential explanation of the Mania is that inexperienced investors were expropriated by railway insiders. Although we find evidence that investors with less experience tended to earn lower returns on their investments in new projects and were more likely to lose money during the downturn, we find no evidence to suggest that they were expropriated by railway insiders. Indeed, despite their access to power and insider knowledge, the investments of railway insiders performed no better than those made by 
the business and middle classes. This evidence appears to partially absolve these vested interests from acting in an opportunistic fashion during the Mania.

All of this evidence raises a puzzle: why did so many people invest in railway shares given that they turned out to be a poor investment ex post? One possibility is that there were insufficient outlets for a growing amount of savings, as the National Debt was not growing and there were few alternative investment assets. Although this may have determined stock returns in the long run, it is unlikely to have caused the sharp reversal in railway stock prices in the mid-1840s. Another possibility is that investors were simply riding the "bubble," and hoping to get out before its eventual demise or before they had to pay calls on capital. Another possible explanation could be that investors at the time were unaware that they were living through a period where new technology was being rapidly adopted, and as the probability of adoption increased, the rate at which cash flows were discounted increased, thus causing stock prices to fall. ${ }^{67}$ Notably, other famous "bubble" episodes such as the 1825 bubble in Britain, the U.S. case of 1928-29, and the dotcom episode of the 1990s have all been associated with concentrated investment in new investment opportunities. ${ }^{68}$ Another potential explanation is that there was political failure in that the UK Parliament, particularly in the autumn of 1845, did not ration railway schemes, and thus prevent wasteful competition. ${ }^{69}$ The effect of this political failure may have been to lower future cash flows, and hence railway stock prices. Future research should attempt to test these various explanations.

The collapse of railway shares in the late 1840s resulted in great difficulties for railway companies who needed capital to expand and improve their network. Investors were generally reluctant to fund smaller railways, and even larger entities had to innovate by issuing preferred stock and debentures to raise the necessary capital. By the early 1860s, the companies that were successful at doing this were producing the earnings that had been anticipated by investors in the 1840 s, but even this was temporary, with railway profitability declining from the 1870 s onwards. $^{70}$ Consequently, a further area of research is the extent to which the Railway Mania affected the subsequent financing and development of British railways.

\section{GARETH CAMPBELL}


Gareth Campbell is a Lecturer in Finance at Queen's University Belfast. His research, which has focussed on asset pricing bubbles and financial history, has been published in Economic History Review and Explorations in Economic History. He was awarded the Economic History Society New Researcher Prize in 2009.

\section{JOHN D. TURNER}

John D. Turner is a Professor of Finance and Financial History at Queen's University Belfast. He has been a Houblon-Norman Fellow at the Bank of England and the Alfred D. Chandler Jr. International Visiting Scholar at the Harvard Business School. He has published articles on free banking, historical banking crises, law and finance, the evolution of limited liability, wealth inequality in the long-run, and the development of the Victorian equity market. His work on these topics has been published in Business History, Economic History Review, Explorations in Economic History, and Journal of Economy History amongst others. He is currently working on a project which is examining ownership and control of British corporations in the nineteenth century.

Thanks to the ESRC (RES-000-22-1391) for financial support. The assistance of archivists at the National Archives, HSBC, and at the Halifax-Bank of Scotland was much appreciated. Jill Turner provided great research assistance. Thanks also to Graeme Acheson, Rawi Abdelal, Catherine Duggan, Walter Friedman, Geoff Jones, Tom Nicholas, Aldo Musacchio, Noel Maurer, Elisabeth Koll, Patrick Fridenson, Ramana Nanda, and participants at a Harvard Business School business history seminar for their helpful comments.

1 Michael J. Brennan, “How Did It Happen?” Economic Notes 33 (2004): 3; Charles P. Kindleberger, Manias, Panics, and Crashes: A History of Financial Crises (New York, 1996, 3rd ed.), 2526; Kindleberger, A Financial History of Western Europe (London, 1984), 272; Charles Mackay, Memoirs of Extraordinary Popular Delusions and the Madness of Crowds (London, 1856, 3rd ed.), 14, 45, 89.

${ }^{2}$ Notable exceptions include Robin Greenwood and Stefan Nagel, "Inexperienced Investors and bubbles" Journal of Financial Economics 93 (2009): 239-58; Ann M. Carlos and Larry Neal, "The MicroFoundations of the Early London Capital Market: Bank of England Shareholders during and after the South Sea Bubble" Economic History Review 59 (2006): 498-538.; Peter Temin and Hans-Joachim Voth, "Riding the South Sea Bubble" American Economic Review 94 (2004): 1654-68.

${ }^{3}$ Mackay, Memoirs of Extraordinary Popular Delusions, 84; Anon., "The Beauty of Bubbles: Booms and Busts', The Economist 389 (2008): 115; Rande W. Kostal, Law and English Railway Capitalism (Oxford, 1994), 29. The South Sea Bubble, which was central in Mackey's book, coloured perceptions of stock investment well into the nineteenth century (Ranald C. Michie, "Gamblers, Fools, Victims, or Wizards? The British Investor in the Public Mind, 1850-1930” in David R. Green, Alaistair 
Owens, Josephine Maltby and Janette Rutterford (eds.), Men, Women, and Money: Perspectives on Gender, Wealth, and Investment 1850-1930 (Oxford, 2011), 156-83), and the Railway Mania was regarded as its reincarnation.

${ }^{4}$ James Taylor, "Business in Pictures: Representations of Railway Enterprise in the Satirical Press in Britain 1845-1870" Past and Present 189 (2005): 118. See Ranald C. Michie, Money, Mania and Markets: Investment, Company Formation and the Stock Exchange in Nineteenth-Century Scotland (Edinburgh, 1981), 96 on the impecunious investing in railways shares. S. A. Broadbridge, "The Sources of Railway Share Capital" in M. C. Reed (ed.) Railways in the Victorian Economy: Studies in Finance and Economic Growth (New York, 1968), 204 implies that the impecunious clerk played an active part in the 1845 Mania. See Ranald C. Michie, Guilty Money: The City of London in Victorian and Edwardian Culture, 1815-1914 (London, 2009), 23-29 and Michie, "Gamblers, Fools, Victims or Wizards?”, 170-1 for additional literary references to and public perception of investors at this time.

5 Broadbridge, "Sources of Railway Share Capital", 204-6; Kindleberger, Mania, Panics and Crashes, 25; Anon., "History of Bank of England", 512; The Banker's Magazine 12 (1863): 510-1; The Times, July $15^{\text {th }} 1845$, 5; John Francis, A History of the English Railway: Its Social Relations and Revelations, 1820-1845 (1851, 2 vols.), vol. 2, 195; Joseph Lee, "The Provision of Capital for Early Irish Railways, 1830-53" Irish Historical Studies 16 (1968): 39; Herbert Spencer, Railway Morals and Railway Policy (London, 1855), 14.

${ }^{6}$ Broadbridge, "Sources of Railway Share Capital", 206. Several contemporary commentators, however, provide a more nuanced view - see Anon., "History of Bank of England", 510-1; David M. Evans, The Commercial Crisis, 1847-1848 (London, 1849, $2^{\text {nd }}$ ed.), 52.

7 Earl A. Thompson and Charles A. Hickson, "Predicting Bubbles" Global Business and Economics Review 8 (2004): 217-46; Rob A. Bryer, “Accounting for the 'Railway Mania' of 1845-a Great Railway Swindle?" Accounting, Organisations and Society, 16 (1991): 439-86.

${ }^{8}$ See Michie, “Gamblers, Fools, Victims or Wizards?”; Josephine Maltby, Janette Rutterford, David Green, Steven Ainscough and Carien van Mourik, "The Evidence for 'Democratization' of Share Ownership in Great Britain in the Early Twentieth Century" in David R. Green, Alaistair Owens, Josephine Maltby and Janette Rutterford (eds.), Men, Women, and Money: Perspectives on Gender, Wealth, and Investment 1850-1930 (Oxford, 2011), 184-206; Janette Rutterford and Josephine Maltby, “ 'The Widow, the Clergyman and the Reckless': Women Investors in England 1830-1914" Feminist Economics 12 (2006): 111-38.

${ }^{9}$ Studies of bank investors in the nineteenth century include B. L. Anderson and Philip L. Cottrell, "Another Victorian Capital Market: A Study of Banking and Bank Investors on Merseyside" Economic History Review 28 (1975): 600-15; Lucy Newton and Philip L. Cottrell, "Female Investors in the First English and Welsh Commercial Joint-Stock Banks" Accounting, Business and Financial History, 16 (2006): 315-40; John D. Turner, "Wider Share Ownership?: Investors in English Bank Shares, 1826-1900" Economic History Review 62 (2009): 167-92; Graeme G. Acheson and John D. Turner, "Investor 
Behaviour in a Nascent Capital Market: Scottish Bank Shareholders in the Nineteenth Century” Economic History Review 64 (2011): 188-213. The important studies of pre-Mania railway investors include Broadbridge, "Sources of Railway Share Capital”; S. A. Broadbridge, Studies in Railway Expansion and the Capital Market in England 1825-1873 (London, 1970); Harold Pollins, "The Finances of the Liverpool and Manchester Railway" Economic History Review 5 (1952): 90-7; M. C. Reed, "Railways and the Growth of the Capital Market" in M. C. Reed (ed.) Railways in the Victorian Economy: Studies in Finance and Economic Growth (New York, 1968); M. C. Reed, Investment in Railways in Britain 1820-1844: A Study in the Development of the Capital Market (Oxford, 1975); Lee, "Provision of Capital"; Wray Vamplew, "Sources of Scottish Railway Share Capital before 1860" Scottish Journal of Political Economy 17 (1970): 425-40.

${ }^{10}$ The Economist, October 4, 1845, 949

${ }^{11}$ Railway Times: November 9, 1844, 1309; August 16, 1845 1288; April 25, 1846, 578.

${ }^{12}$ The Times, November 17, 1845, 4 This figure underestimates the extent of promotion as 335 companies not on this list went on to petition Parliament (The Times, January 14, 1846, 6).

${ }^{13}$ The deposit had been reduced to five percent just prior to the Mania, but was increased back to 10 percent during the Mania (Anon., "History of Bank of England", 515).

${ }^{14}$ Promoters also used their personal contacts as well as agents to help raise the necessary finance (Harold Pollins, "The Marketing of Railway Shares in the First Half of the Nineteenth Century" Economic History Review 7 (1954): 230-9; Reed, Investment in Railways, 86).

${ }^{15}$ See, for example, Herapath"s Railway Journal and the Railway Times.

${ }^{16}$ Pollins, "Marketing of Railway Shares", 238.

${ }^{17}$ Reed, Investment in Railways, 89.

${ }^{18}$ Anon., The Railway Speculator's Memorandum Book, Ledger, and General Guide to Secure Share Dealing (London, 1845), 7; Reed, Investment in Railways, 89.

${ }^{19}$ Anon., A Short and Sure Guide to Railway Speculation (London, 1845), 10.

${ }^{20}$ Kostal, Law and English Railway Capitalism, 76-7.

${ }^{21}$ Broadbridge, "Sources of railway share capital", 185; Reed, Investment in railways, 100-1. Of course, even share registers, if they existed, may not have picked up all speculative activity as shares could be shorted or bought and sold within the stock exchange"s fortnightly settlement period.

${ }^{22}$ Broadbridge, "Sources of Railway Share Capital", 185.

${ }^{23}$ See Vamplew, "Scottish Railway Share Capital”, 432 who used the subscriber lists in his study of Scottish railways.

${ }^{24}$ Anon., The Railway Investment Guide: How to Make Money in Railway Shares: A Series of Hints and Advice to Parties Speculating (1845), 13.

${ }^{25}$ British Parliamentary Papers, First and Second Reports from the S.C. of the House of Lords on Audit of Railway Accounts (1849, X), QQ. 2624-5.

${ }^{26}$ British Parliamentary Papers, Return of Railway Subscribers, (1845, XL), 1. 
${ }^{27}$ British Parliamentary Papers, Return of Railway Subscribers, (1846, XXXVIII).

${ }^{28}$ The Times, July $25^{\text {th }}$ and August $1^{\text {st }} 1845$; Francis, A History of the English Railway, vol. 2, 193 4; Reed, Investment in Railways, 97.

${ }^{29}$ The Bankers' Magazine, October 1846, 51; The Bankers' Magazine, November 1846, 119; The Railway Times, August $2^{\text {nd }} 1845,1160$; The Times, July $15^{\text {th }} 1845,5$.

${ }^{30}$ British Parliamentary Papers, Report from the S.C. on the London and York Railway Subscription List (1845, X), 136-7. A further three individuals were found to be impecunious and unable to pay the sums that they had subscribed for.

31 British Parliamentary Papers, Report from the S.C. on the London and York Railway Subscription List, iv.

${ }^{32}$ Reed, Investment in Railways, 84.

${ }^{33}$ Broadbridge, "Sources of Railway Share Capital”, 207; Reed, Investment in Railways, 84.

${ }^{34}$ Reed, Investment in Railways, 111.

35 British Parliamentary Papers, Report from the S.C. on the London and York Railway Subscription List, 136-8.

${ }^{36}$ Broadbridge, "Sources of Railway Share Capital", 193.

${ }^{37}$ Pollins, "Marketing of Railway Shares", 238. On the absence of favouritism in the allotment of railway shares see The Railway Shareholder's Pocket-book and Almanac (London, 1846), 56.

${ }^{38}$ Broadbridge, "Sources of Railway Share Capital”, 194.

${ }^{39}$ Anon., The Railway Investment Guide, 9.

${ }^{40}$ Pollins, Britain's Railways, 37.

${ }^{41}$ Although we are not looking at trading per se, we are implicitly using the concepts of information and noise traders as articulated by Fischer Black. See Fischer Black, "Noise" Journal of Finance 41 (1986): 529-43. In Black"s model, some information traders will lose money and some noise traders will make money, but noise traders as a group will lose money and information traders as a group will make money.

42 "Agriculture" includes farmer, cattle and corn dealers, yeomen, millers etc.; "Bankers" include bank directors, managers, senior officials as well as private bankers; "Other finance" includes accountants, actuaries, and insurance brokers / agents; "Legal professionals" includes advocates, barristers, solicitors, and writers to the signet; "Manufacturers" are those whose main business is manufacturing; "Merchants" include those described as merchants as well as brokers, dealers, agents, printers, publishers, and shipowners; "Nobility" includes peers as well baronets and knights; "Politicians" is mainly composed of MPs, but there are also a few mayors and aldermen included in this category; "Professionals" includes architects, company secretaries, dentists, doctors, engineers, senior civil servants, and surgeons; "Retailers" are those who retail goods or provide services via shops to the general public; "Skilled working class" includes tradesmen and occupations which required some degree of education / training; "Unskilled working class" 
consists mainly of labourers. "White collar" include those occupations usually considered the preserve of the middle and lower-middle classes - teachers, bank officials, civil servants, bookkeepers etc..

${ }^{43}$ See Reed, Investment in Railways, 110 on this.

${ }^{44}$ Spencer, Railway Morals, 16-20.

${ }^{45}$ Brennan, "How did it happen?": 3.

${ }^{46}$ Arthur D. Gayer, W. W. Rostow and Anna Jacobson Schwartz, The Growth and Fluctuation of the British Economy (Oxford, 1953), 380, 410; Reed, "Railways and the Growth of the Capital Market", 182.

${ }^{47}$ Authors' calculations from Course of the Exchange, Dec. $31^{\text {st }} 1844$. There were over 43,000 shareholders in these banks. Authors' calculations based on data in The Banking Almanac (1845), 106-21.

${ }^{48}$ Lists of proprietors of The Bank of Scotland, Royal Bank of Scotland, British Linen Company and the other banks in Scotland (1846), Halifax-Bank of Scotland Archives, NRAS 1110/13/192/1. Although it was published in 1846, it is more than likely that the data was gathered from 1845 shareholder lists.

${ }^{49}$ HSBC Archives: Sheffield and Hallamshire Share Registers (598/1, 598/2).

${ }^{50}$ Lucy A. Newton, "Regional Bank-Industry Relations during the Mid-Nineteenth Century: Links between Bankers and Manufacturing in Sheffield, c. 1850 to c.1885" Business History 38 (1996): 64-83.

${ }^{51}$ The Banking Almanac (1845), 112-3.

${ }^{52}$ Turner, "Wider Share Ownership", 187.

${ }^{53}$ Broadbridge, "Sources of Railway Share Capital", 186; Reed, Investment in Railways, 193-5.

${ }^{54}$ For pre-Mania London investment in railways see Reed, Investment in Railways, 146-92; Broadbridge, "Sources of Railway Share Capital", 186-7.

${ }^{55}$ This also illustrates the large concentration of investors in London.

${ }^{56}$ On this issue see Broadbridge, "Sources of Railway Share Capital", 193; Bryer "Accounting for the 'Railway Mania"': 483.

${ }^{57}$ For the sake of this analysis, London is considered as a county. The pre-Mania railways tended to attract a disproportionate amount of investment from towns and regions which they served - see Broadbridge, "Sources of Railway Share Capital”, 193

${ }^{58}$ This is somewhat contrary to Thomas, Provincial stock exchanges, 33 who suggests that local sources of finance were unimportant in this period.

${ }^{59}$ The price/par ratio reflects the differences between the market price of shares and the amount that investors had already paid up.

${ }^{60}$ Anon., The Railway Investment Guide, 10.

${ }^{61}$ The upper classes may have invested in schemes which may not have provided much in the way of financial return, but may have provided positive externalities for them in terms of selling land to railway companies at above market prices or being able to transport agricultural produce at lower cost. Notably, the upper classes were not more likely to invest in local railways than other investors. 
${ }^{62}$ Spencer, Railway Morals, 14 suggests that MPs were not immune from acting in an opportunistic manner during the Mania.

${ }^{63}$ See Taylor, "Business in pictures": 121-2 who highlights that railway directors were portrayed as charlatans during the Mania.

${ }^{64}$ Great Western Railway holders of $£ 100$ shares and $£ 20$ shares 1843,1845 and 1848 (National Archives, RAIL 251/28, 29, 32, 50, 52 and 54).

${ }^{65}$ See Reed, Investment in Railways, 203.

${ }^{66}$ Anon. A Short and Sure Guide, 11.

${ }^{67}$ See Lubos Pástor and Pietro Veronesi, "Technological Revolutions and Stock Prices” American Economic Review 99 (2009): 1451-83 for theoretical work on this.

${ }^{68}$ Larry Neal, "The Financial Crisis of 1825 and the Restructuring of the British Financial System" Federal Reserve Bank of St. Louis Review May/June (1998): 53-76; Eugene N. White, "The Stock Market Boom and Crash of 1929 Revisited" Journal of Economic Perspectives 4 (1990): 67-83; Tom Nicholas, 'Does Innovation Cause Stock Market Runups? Evidence from the Great Crash' American Economic Review 98 (2009): 1370-96; Pástor and Veronesi, “Technological revolutions”.

${ }^{69}$ Mark Casson, The World's First Railway System: Enterprise, Competition, and Regulation on the Railway Network in Victorian Britain (Oxford, 2009).

70 A. G. Kenwood, "Railway investment in Britain" Economica 32 (1965): 318-9; David Chambers, Nicholas F. R. Crafts and Brian R. Mitchell, "How Good was the Profitability of British Railways, 1870-1912?” Economic History Review 64 (2011): 798-831. 
Table 1

Railway Investors during the Mania

\begin{tabular}{|c|c|c|c|c|c|c|c|c|c|}
\hline & & \multicolumn{4}{|c|}{1845 Parliamentary list - the run-up phase } & \multicolumn{4}{|c|}{1846 Parliamentary list - the peak of the Mania } \\
\hline & & $\begin{array}{l}\% \\
\text { investors }\end{array}$ & $\%$ capital & $\begin{array}{l}\text { Average no. } \\
\text { investments }\end{array}$ & $\begin{array}{l}\text { Average value } \\
\text { of investments } \\
\text { (f) }\end{array}$ & $\%$ investors & $\%$ capital & $\begin{array}{l}\text { Average no. } \\
\text { investments }\end{array}$ & $\begin{array}{l}\text { Average value of } \\
\text { investments }(\mathfrak{E})\end{array}$ \\
\hline \multirow{3}{*}{ Inexperienced } & Clergymen & 0.9 & 0.6 & 2.0 & 2,161 & 0.4 & 0.3 & 1.5 & 6,631 \\
\hline & Skilled working class & 0.6 & 0.1 & 1.4 & 701 & 0.1 & 0.0 & 1.1 & 3,258 \\
\hline & Unskilled working class & 0.4 & 0.0 & 1.3 & 269 & 0.1 & 0.0 & 1.3 & 3,446 \\
\hline \multirow[t]{2}{*}{ Women } & Spinsters & 4.5 & 0.9 & 1.6 & 632 & 0.9 & 0.3 & 1.1 & 3,069 \\
\hline & Widows & 2.0 & 0.5 & 1.6 & 757 & 0.6 & 0.2 & 1.1 & 3,920 \\
\hline \multirow[t]{2}{*}{ Middle class } & Professionals & 4.8 & 3.1 & 1.9 & 2,214 & 5.2 & 3.8 & 1.5 & 7,066 \\
\hline & White collar & 6.7 & 2.8 & 1.7 & 1,401 & 4.0 & 2.3 & 1.4 & 5,518 \\
\hline \multirow{3}{*}{ Upper class } & Army \& navy officers & 1.6 & 2.5 & 1.9 & 5,301 & 2.0 & 2.0 & 1.9 & 9,830 \\
\hline & Gentlemen & 25.2 & 31.5 & 1.9 & 4,182 & 27.9 & 28.8 & 1.7 & 9,990 \\
\hline & Nobility & 0.7 & 2.0 & 1.9 & 10,247 & 1.5 & 2.3 & 2.0 & 15,044 \\
\hline Merchants & Merchants & 21.4 & 29.9 & 2.1 & 4,691 & 24.6 & 31.2 & 1.9 & 12,326 \\
\hline \multirow[t]{2}{*}{ Business } & Manufacturers & 9.3 & 5.9 & 1.9 & 2,153 & 7.7 & 6.5 & 1.7 & 8,208 \\
\hline & Retailers & 7.1 & 2.3 & 1.7 & 1,077 & 3.2 & 1.7 & 1.3 & 5,038 \\
\hline \multirow[t]{2}{*}{ Finance } & Bankers & 1.9 & 4.7 & 2.4 & 8,133 & 3.1 & 3.6 & 2.1 & 11,181 \\
\hline & Other Finance & 1.1 & 0.9 & 1.9 & 2,557 & 1.0 & 0.6 & 1.6 & 6,065 \\
\hline
\end{tabular}




\begin{tabular}{|c|c|c|c|c|c|c|c|c|c|}
\hline & Stockbrokers & 2.0 & 2.6 & 2.6 & 4,470 & 3.6 & 3.3 & 2.0 & 9,044 \\
\hline Political & Politicians & 0.3 & 1.0 & 2.3 & 10,577 & 1.2 & 3.1 & 3.2 & 25,974 \\
\hline \multirow[t]{2}{*}{ Other } & Agriculture & 2.6 & 0.6 & 1.4 & 815 & 1.4 & 0.7 & 1.3 & 5,053 \\
\hline & Total & 24,844 & $£ 83.2 \mathrm{~m}$ & 1.9 & 3,349 & 12,533 & $£ 121.4 \mathrm{~m}$ & 1.7 & 9,693 \\
\hline
\end{tabular}

Sources: Authors' calculations based on Return of Railway Subscribers, (P.P. 1845, XL) and Return of Railway Subscribers, (P.P. 1846, XXXVIII).

Notes: The 1845 Parliamentary list includes investors who invested sums greater and less than $£ 2,000$, whereas the 1846 list only reports those who invested over $£ 2,000$. 
Table 2

Large Investors during the Mania

\begin{tabular}{|c|c|c|c|c|c|c|c|c|c|}
\hline & & \multicolumn{4}{|c|}{ Investors who invested in both the run-up and at the peak } & \multicolumn{4}{|c|}{ The top percentile of investors during Mania } \\
\hline & & $\begin{array}{l}\text { No. } \\
\text { investors }\end{array}$ & $\begin{array}{l}\text { \% capital in } \\
1845-46\end{array}$ & $\begin{array}{l}\text { Average no. } \\
\text { investments }\end{array}$ & $\begin{array}{l}\text { Average value } \\
\text { of investments } \\
\text { per investor (f) }\end{array}$ & $\begin{array}{l}\text { No. } \\
\text { Investors }\end{array}$ & $\begin{array}{l}\text { \% capital } \\
\text { in } 1845-46\end{array}$ & $\begin{array}{l}\text { Average no. } \\
\text { investments }\end{array}$ & $\begin{array}{l}\text { Average } \\
\text { value } \\
\text { of } \\
\text { investments } \\
\text { per investor } \\
(\mathfrak{f})\end{array}$ \\
\hline & Clergymen & 9 & 0.1 & 5.7 & 24,175 & 2 & 0.1 & 10.0 & 130,900 \\
\hline \multirow[t]{2}{*}{ Inexperienced } & Skilled working class & 1 & 0.0 & 3.0 & 15,000 & 0 & - & - & - \\
\hline & Unskilled working & 1 & 0.0 & 4.0 & 5,360 & 0 & - & - & - \\
\hline \multirow[t]{2}{*}{ Women } & Spinsters & 15 & 0.0 & 2.4 & 5,542 & 0 & - & - & - \\
\hline & Widows & 6 & 0.0 & 3.2 & 5,073 & 0 & - & - & - \\
\hline \multirow[t]{2}{*}{ Middle class } & Professionals & 158 & 1.1 & 4.8 & 14,842 & 5 & 0.5 & 5.6 & 184,845 \\
\hline & White collar & 100 & 0.6 & 4.6 & 12,714 & 1 & 0.1 & 4.0 & 170,000 \\
\hline \multirow{3}{*}{ Upper class } & Army \& navy officers & 53 & 1.1 & 6.2 & 43,771 & 8 & 0.9 & 13.8 & 228,372 \\
\hline & Gentlemennn & 852 & 13.6 & 5.7 & 32,621 & 106 & 9.3 & 13.3 & 179,708 \\
\hline & Nobility & 25 & 0.8 & 6.6 & 66,336 & 8 & 1.0 & 8.5 & 258,455 \\
\hline Merchants & Merchants & 988 & 17.0 & 6.1 & 35,270 & 125 & 12.4 & 13.3 & 202,922 \\
\hline \multirow[t]{2}{*}{ Business } & Manufacturers & 253 & 2.7 & 5.6 & 21,555 & 16 & 1.3 & 17.4 & 161,154 \\
\hline & Retailers & 96 & 0.4 & 4.5 & 9,172 & 3 & 0.2 & 4.7 & 112,927 \\
\hline \multirow[t]{3}{*}{ Finance } & Bankers & 146 & 2.3 & 6.3 & 32,190 & 20 & 1.7 & 11.9 & 172,126 \\
\hline & Other Finance & 28 & 0.2 & 4.9 & 11,940 & 1 & 0.1 & 1.0 & 150,150 \\
\hline & Stockbrokers & 124 & 1.3 & 6.6 & 21,157 & 5 & 0.3 & 17.6 & 130,393 \\
\hline Political & Politicians & 39 & 1.3 & 7.7 & 66,715 & 14 & 1.1 & 10.6 & 158,260 \\
\hline
\end{tabular}




\begin{tabular}{|c|c|c|c|c|c|c|c|c|c|}
\hline Legal & Legal professionals & 324 & 3.8 & 5.0 & 23,980 & 22 & 2.1 & 12.3 & 192,825 \\
\hline \multirow[t]{3}{*}{ Other } & Agriculture & 27 & 0.2 & 4.7 & 14,566 & 1 & 0.1 & 8.0 & 112,050 \\
\hline & Unknown & 3 & 0.1 & 7.0 & 48,478 & 5 & 0.3 & 4.6 & 141,297 \\
\hline & Total & 3,248 & 46.6 & 5.7 & 29,399 & 342 & 31.3 & 12.8 & 187,436 \\
\hline
\end{tabular}

Source: Authors' calculations based on Return of Railway Subscribers, (P.P. 1845, XL) and Return of Railway Subscribers, (P.P. 1846, XXXVIII).

Notes: Investors who invested in both the runup and the peak refers to those investors who appeared on subscription lists in both 1845 and 1846. The top percentile of investors refers to the top one percent of investors when they are ranked according to the total amount which they invested during the Mania. 


\section{Table 3}

Investors during the Mania Who Were Also Provisional Committee (PC) Members

\begin{tabular}{|c|c|c|c|c|c|c|c|c|}
\hline & & & Average no. & investments & $\begin{array}{l}\text { Average size } \\
\text { in each comp }\end{array}$ & $\begin{array}{l}\text { investment } \\
\text { y (f) }\end{array}$ & $\begin{array}{l}\% \text { of total cap } \\
1846\end{array}$ & 1 in 1845 and \\
\hline & & No. of investors & $\begin{array}{l}\text { In firms in } \\
\text { which was a } \\
\text { PC member }\end{array}$ & In all firms & $\begin{array}{l}\text { In firms in } \\
\text { which was a } \\
\text { PC member }\end{array}$ & In all firms & $\begin{array}{l}\text { In firms in } \\
\text { which was a } \\
\text { PC member }\end{array}$ & In all firms \\
\hline & Clergymen & 8 & 1.3 & 2.1 & 3,826 & 7,942 & 0.0 & 0.2 \\
\hline \multirow[t]{4}{*}{ Inexperienced } & Skilled working & & & & & & & \\
\hline & class & 4 & 1.3 & 1.5 & 5,600 & 5,500 & 0.0 & 0.0 \\
\hline & Unskilled & & & & & & & \\
\hline & working class & 0 & - & - & - & - & 0.0 & 0.0 \\
\hline \multirow[t]{2}{*}{ Women } & Spinsters & 0 & - & - & - & - & 0.0 & 0.0 \\
\hline & Widows & 0 & - & - & - & - & 0.0 & 0.0 \\
\hline \multirow[t]{4}{*}{ Middle class } & Professionals & 81 & 1.3 & 1.8 & 3,966 & 3,488 & 0.5 & 0.6 \\
\hline & White collar & 43 & 1.4 & 2.0 & 3,941 & 3,915 & 0.3 & 0.4 \\
\hline & Army \& navy & & & & & & & \\
\hline & officers & 61 & 1.3 & 2.4 & 4,318 & 4,526 & 0.4 & 0.7 \\
\hline \multirow[t]{2}{*}{ Upper class } & Gentlemen & 653 & 1.4 & 2.2 & 5,424 & 5,738 & 5.5 & 9.3 \\
\hline & Nobility & 63 & 1.3 & 2.3 & 6,344 & 5,840 & 0.6 & 1.0 \\
\hline
\end{tabular}




\begin{tabular}{|c|c|c|c|c|c|c|c|c|}
\hline Merchants & Merchants & 566 & 1.6 & 3.0 & 7,001 & 6,647 & 6.9 & 12.5 \\
\hline \multirow[t]{2}{*}{ Business } & Manufacturers & 174 & 1.3 & 2.3 & 4,972 & 4,812 & 1.2 & 2.1 \\
\hline & Retailers & 40 & 1.1 & 1.8 & 2,380 & 2,723 & 0.1 & 0.2 \\
\hline \multirow[t]{3}{*}{ Finance } & C Bankers & 95 & 1.4 & 2.9 & 5,402 & 5,269 & 0.8 & 1.6 \\
\hline & Other Finance & 4 & 1.3 & 2.0 & 3,620 & 3,200 & 0.0 & 0.0 \\
\hline & Stockbrokers & 7 & 1.0 & 2.1 & 6,143 & 6,640 & 0.0 & 0.1 \\
\hline Political & Politicians & 80 & 1.7 & 3.4 & 5,819 & 5,264 & 0.9 & 1.6 \\
\hline \multirow[t]{2}{*}{ Legal } & Legal & & & & & & & \\
\hline & professionals & 127 & 1.4 & 2.3 & 5,692 & 4,891 & 1.1 & 1.6 \\
\hline \multirow[t]{3}{*}{ Other } & $\{$ Agriculture & 26 & 1.3 & 1.7 & 2,674 & 2,918 & 0.1 & 0.1 \\
\hline & Unknown & 26 & 1.2 & 1.5 & 5,306 & 5,827 & 0.2 & 0.3 \\
\hline & Total & 2,058 & 1.4 & 2.5 & 5,728 & 5,677 & 18.5 & 32.4 \\
\hline
\end{tabular}

Sources: Authors' calculations based on Return of Railway Subscribers, (P.P. 1845, XL), Return of Railway Subscribers, (P.P. 1846, XXXVIII), and various issues of Railway Times.

Notes: The sample is restricted to railway schemes for which we have provisional committee data available. 
Table 4

OLS Regressions: Investor Characteristics and First-Day Investment Returns

\begin{tabular}{|c|c|c|c|c|c|c|c|c|c|}
\hline & (1) & (2) & (3) & (4) & (5) & (6) & (7) & (8) & (9) \\
\hline Inexperienced & $\begin{array}{l}-0.140 * * \\
(0.066)\end{array}$ & & & & $\begin{array}{l}-0.214 * * * \\
(0.066)\end{array}$ & & & $\begin{array}{l}-0.290 * * * \\
(0.071)\end{array}$ & \\
\hline Women & $\begin{array}{l}-0.240 * * * \\
(0.044)\end{array}$ & & & & $\begin{array}{l}-0.281^{* * *} \\
(0.044)\end{array}$ & & & $\begin{array}{l}-0.482 * * * \\
(0.049)\end{array}$ & \\
\hline Middle class & $\begin{array}{l}-0.090 * * * \\
(0.024)\end{array}$ & & & & $\begin{array}{l}-0.100^{* * * *} \\
(0.023)\end{array}$ & & & $\begin{array}{l}-0.197 * * * \\
(0.027)\end{array}$ & \\
\hline Upper class & $\begin{array}{l}-0.108 * * * \\
(0.017)\end{array}$ & & & & $\begin{array}{l}-0.078^{* * * *} \\
(0.017)\end{array}$ & & & $\begin{array}{l}-0.151^{* * * *} \\
(0.019)\end{array}$ & \\
\hline Business & & $\begin{array}{l}0.242 * * * \\
(0.023)\end{array}$ & & & & $\begin{array}{l}0.217 * * * \\
(0.022)\end{array}$ & & & $\begin{array}{l}0.383 * * * \\
(0.031)\end{array}$ \\
\hline Merchant & & $\begin{array}{l}0.106 * * * \\
(0.018)\end{array}$ & & & & $\begin{array}{l}0.094 * * * \\
(0.018)\end{array}$ & & & $\begin{array}{l}0.169 \text { *** } \\
(0.022)\end{array}$ \\
\hline Finance & & $\begin{array}{l}-0.033 \\
(0.029)\end{array}$ & & & & $\begin{array}{l}-0.020 \\
(0.030)\end{array}$ & & & $\begin{array}{l}-0.041 \\
(0.032)\end{array}$ \\
\hline Politician & & $\begin{array}{l}-0.051 \\
(0.061)\end{array}$ & & & & $\begin{array}{l}0.066 \\
(0.065)\end{array}$ & & & $\begin{array}{l}0.152^{* *} \\
(0.073)\end{array}$ \\
\hline Legal & & $\begin{array}{l}0.012 \\
(0.028)\end{array}$ & & & & $\begin{array}{l}0.057 * * \\
(0.028)\end{array}$ & & & $\begin{array}{l}0.100^{* * * *} \\
(0.033)\end{array}$ \\
\hline Director & & & $\begin{array}{l}0.062 \\
(0.044)\end{array}$ & & $\begin{array}{l}0.081 \\
(0.050)\end{array}$ & $\begin{array}{l}0.087 * \\
(0.050)\end{array}$ & & $\begin{array}{l}0.113^{*} \\
(0.059)\end{array}$ & $\begin{array}{l}0.120 * * \\
(0.059)\end{array}$ \\
\hline Chairman & & & $\begin{array}{l}0.104 \\
(0.112)\end{array}$ & & $\begin{array}{l}0.119 \\
(0.112)\end{array}$ & $\begin{array}{l}0.126 \\
(0.112)\end{array}$ & & $\begin{array}{l}0.068 \\
(0.128)\end{array}$ & $\begin{array}{l}0.079 \\
(0.128)\end{array}$ \\
\hline Prov. Comm. & & & & & & & $\begin{array}{l}0.025 \\
(0.031)\end{array}$ & $\begin{array}{l}-0.053 \\
(0.032)\end{array}$ & $\begin{array}{l}-0.038 \\
(0.032)\end{array}$ \\
\hline London & & & & $\begin{array}{l}-0.155^{* * * *} \\
(0.017)\end{array}$ & $\begin{array}{l}-0.125 \text { *** } \\
(0.018)\end{array}$ & $\begin{array}{l}-0.111 * * * \\
(0.018)\end{array}$ & & $\begin{array}{l}-0.140 * * * \\
(0.018)\end{array}$ & $\begin{array}{l}-0.118^{* * * *} \\
(0.018)\end{array}$ \\
\hline Lancashire & & & & $\begin{array}{l}-0.119 * * * \\
(0.026)\end{array}$ & $\begin{array}{l}-0.119^{* * * *} \\
(0.026)\end{array}$ & $\begin{array}{l}-0.122 * * * \\
(0.026)\end{array}$ & & $\begin{array}{l}-0.007 \\
(0.029)\end{array}$ & $\begin{array}{l}-0.010 \\
(0.029)\end{array}$ \\
\hline Local & & & & $\begin{array}{l}0.088 * * * \\
(0.015)\end{array}$ & $\begin{array}{l}0.217 * * * \\
(0.016)\end{array}$ & $\begin{array}{l}0.202 * * * \\
(0.016)\end{array}$ & & $\begin{array}{l}0.416^{* * * *} \\
(0.023)\end{array}$ & $\begin{array}{l}0.399 * * * \\
(0.023)\end{array}$ \\
\hline InvestBoth4546 & & & & & $\begin{array}{l}-0.030 \\
(0.020)\end{array}$ & $\begin{array}{l}-0.017 \\
(0.020)\end{array}$ & & $\begin{array}{l}-0.038 \\
(0.024)\end{array}$ & $\begin{array}{l}-0.016 \\
(0.024)\end{array}$ \\
\hline PortfolioNum & & & & & $\begin{array}{l}0.017 * * * \\
(0.002)\end{array}$ & $\begin{array}{l}0.018 * * * \\
(0.002)\end{array}$ & & $\begin{array}{l}0.013 \text { *** } \\
(0.003)\end{array}$ & $\begin{array}{l}0.013 * * * \\
(0.003)\end{array}$ \\
\hline PortfolioValue & & & & & $\begin{array}{l}-0.000 * * * \\
(0.000)\end{array}$ & $\begin{array}{l}-0.000 * * * \\
(0.000)\end{array}$ & & $\begin{array}{l}-0.000 \\
(0.000)\end{array}$ & $\begin{array}{l}-0.000 \\
(0.000)\end{array}$ \\
\hline Year1846 & & & & & $\begin{array}{l}-0.427 \text { *** } \\
(0.016)\end{array}$ & $\begin{array}{l}-0.414 * * * \\
(0.016)\end{array}$ & & $\begin{array}{l}-0.214 * * * \\
(0.018)\end{array}$ & $\begin{array}{l}-0.195 * * * \\
(0.018)\end{array}$ \\
\hline ShareValue & & & & & $\begin{array}{l}0.000 \\
(0.000)\end{array}$ & $\begin{array}{l}0.000^{*} \\
(0.000)\end{array}$ & & $\begin{array}{l}0.000 \\
(0.000)\end{array}$ & $\begin{array}{l}0.000^{* *} * \\
(0.000)\end{array}$ \\
\hline ParMax & & & & & $\begin{array}{l}-3.377 \text { *** } \\
(0.048)\end{array}$ & $\begin{array}{l}-3.391 * * * \\
(0.048)\end{array}$ & & $\begin{array}{l}-3.190 * * * \\
(0.068)\end{array}$ & $\begin{array}{l}-3.226^{* * * *} \\
(0.069)\end{array}$ \\
\hline Constant & $1.888 * * * *$ & $1.778 * * *$ & $1.841 * *$ & $1.857 * * *$ & $2.260 * * *$ & $2.152 * * *$ & $1.748 * *$ & 2.080 *** & $1.886^{* * * *}$ \\
\hline & $(0.010)$ & $(0.011)$ & $(0.007)$ & $(0.011)$ & $(0.018)$ & $(0.017)$ & (0.009) & $(0.022)$ & (0.019) \\
\hline Observations & 28,951 & 28,951 & 28,951 & 28,951 & 28,043 & 28,043 & 20,061 & 19,782 & 19,782 \\
\hline R-squared & 0.002 & 0.005 & 0.000 & 0.005 & 0.094 & 0.095 & 0.000 & 0.085 & 0.089 \\
\hline
\end{tabular}

Notes: The dependent variable is the price/par ratio on the first day of trading of new railway schemes. $* * *$ $\mathrm{p}<0.01, * * \mathrm{p}<0.05, * \mathrm{p}<0.1$ robust standard errors in parentheses. Inexperienced is a binary variable equal to one if the investor is skilled working class, unskilled working class or clergy; Women is a binary variable equal to one if the investor is a spinster or widow; Middle class is a binary variable equal to one if the investor is from the professional or white collar categories; Upper class is a binary variable equal to one if the investor is from the upper class; Business is a binary variable equal to one if the investor is a manufacturer or retailer; Merchant is a binary variable equal to one if the investor is a merchant; Politician is a binary variable equal to one if the investor is an MP; Finance is a binary variable equal to one if the investor is a banker, stockbroker or works in the financial sector; Legal is a binary variable equal to one if the investor is a member of the legal profession; Director is a binary variable equal to one if the investor is a railway director or secretary; Chairman is a binary variable equal to one if the investor is a railway 
chairman; Prov. Comm. is a binary variable equal to one if the investor is a member of the provisional committee; London is a binary variable equal to one if the investor resides there; Lancashire is a binary variable equal to one if the investor resides in that county; Local is a binary variable equal to one if the investor is from the county of the railway's termini; InvestBoth4546 is a binary variable equal to one if the investor subscribes to railways in both the 1845 and 1846 lists; PortfolioNum is the number of different railways that an investor subscribes to; PortfolioValue is the total value of railway investments made by an investor; Year1846 is a binary variable equal to one if an investment is made in 1846; ShareValue is the value of the investment; ParMax is par value / nominal value i.e., fraction of capital which was called up. 
Table 5

OLS Regressions: Investor Characteristics and Long-run Success

\begin{tabular}{|c|c|c|c|c|c|c|c|c|c|}
\hline & (1) & (2) & (3) & (4) & (5) & (6) & (7) & (8) & (9) \\
\hline \multirow[t]{2}{*}{ Inexperienced } & $-0.135 * *$ & & & & $-0.175 * * *$ & & & $-0.279 * * *$ & \\
\hline & $(0.052)$ & & & & $(0.053)$ & & & $(0.070)$ & \\
\hline \multirow[t]{2}{*}{ Women } & $-0.243 * * *$ & & & & $-0.271 * * *$ & & & $-0.396 * * *$ & \\
\hline & $(0.029)$ & & & & $(0.030)$ & & & $(0.043)$ & \\
\hline \multirow[t]{2}{*}{ Middle class } & $-0.111^{*} * *$ & & & & $-0.111 * * *$ & & & $-0.178 * * *$ & \\
\hline & $(0.018)$ & & & & $(0.018)$ & & & $(0.025)$ & \\
\hline \multirow[t]{2}{*}{ Upper class } & $-0.148 * * *$ & & & & $-0.095 * * *$ & & & $-0.149 * * *$ & \\
\hline & $(0.013)$ & & & & $(0.013)$ & & & $(0.017)$ & \\
\hline \multirow[t]{2}{*}{ Business } & & $0.242^{* * * *}$ & & & & $0.191 * * *$ & & & $0.359 * * *$ \\
\hline & & $(0.022)$ & & & & $(0.021)$ & & & $(0.033)$ \\
\hline \multirow[t]{2}{*}{ Merchant } & & $0.148^{* * * *}$ & & & & $0.108 * * *$ & & & $0.154 * * *$ \\
\hline & & $(0.015)$ & & & & $(0.016)$ & & & $(0.022)$ \\
\hline \multirow[t]{2}{*}{ Finance } & & $-0.033^{*}$ & & & & -0.028 & & & -0.043 \\
\hline & & $(0.020)$ & & & & $(0.020)$ & & & $(0.027)$ \\
\hline \multirow[t]{2}{*}{ Politician } & & -0.052 & & & & 0.082 & & & $0.135 * *$ \\
\hline & & $(0.049)$ & & & & $(0.052)$ & & & $(0.063)$ \\
\hline \multirow[t]{2}{*}{ Legal } & & $0.044 * *$ & & & & $0.078 * * *$ & & & $0.095 * * *$ \\
\hline & & $(0.022)$ & & & & $(0.022)$ & & & $(0.029)$ \\
\hline \multirow[t]{2}{*}{ Director } & & & $0.133 * * *$ & & $0.128 * * *$ & $0.132 * * *$ & & $0.152 * * *$ & $0.159 * * *$ \\
\hline & & & $(0.039)$ & & $(0.043)$ & $(0.043)$ & & $(0.056)$ & $(0.056)$ \\
\hline \multirow[t]{2}{*}{ Chairman } & & & 0.139 & & 0.125 & 0.132 & & 0.143 & 0.153 \\
\hline & & & $(0.102)$ & & $(0.100)$ & $(0.100)$ & & $(0.126)$ & $(0.126)$ \\
\hline \multirow[t]{2}{*}{ Prov. Comm. } & & & & & & & $-0.090 * * *$ & $-0.087 * * *$ & $-0.075 * * *$ \\
\hline & & & & & & & $(0.028)$ & $(0.029)$ & $(0.029)$ \\
\hline \multirow[t]{2}{*}{ London } & & & & $-0.054 * * *$ & -0.006 & 0.004 & & $-0.028^{*}$ & -0.010 \\
\hline & & & & $(0.011)$ & $(0.012)$ & $(0.012)$ & & $(0.015)$ & $(0.015)$ \\
\hline \multirow[t]{2}{*}{ Lancashire } & & & & $0.096 * * *$ & $0.072 * * *$ & $0.070 * * *$ & & $0.184 * * *$ & $0.184 * * *$ \\
\hline & & & & $(0.021)$ & $(0.020)$ & $(0.020)$ & & $(0.027)$ & $(0.027)$ \\
\hline \multirow[t]{2}{*}{ Local } & & & & $0.164 * * *$ & $0.196^{* * * *}$ & $0.184 * * *$ & & $0.437 * * *$ & $0.422 * * *$ \\
\hline & & & & $(0.013)$ & $(0.015)$ & $(0.015)$ & & $(0.023)$ & $(0.023)$ \\
\hline \multirow[t]{2}{*}{ InvestBoth4546 } & & & & & $0.055^{* * * *}$ & $0.065 * * *$ & & $0.048 * *$ & $0.069 * * *$ \\
\hline & & & & & $(0.017)$ & $(0.017)$ & & $(0.023)$ & $(0.023)$ \\
\hline \multirow[t]{2}{*}{ PortfolioNum } & & & & & $0.004 * *$ & $0.004 * *$ & & $0.004 *$ & $0.005^{*}$ \\
\hline & & & & & $(0.002)$ & $(0.002)$ & & $(0.002)$ & $(0.002)$ \\
\hline \multirow[t]{2}{*}{ PortfolioValue } & & & & & -0.000 & $-0.000 *$ & & -0.000 & -0.000 \\
\hline & & & & & $(0.000)$ & $(0.000)$ & & $(0.000)$ & $(0.000)$ \\
\hline \multirow[t]{2}{*}{ Year1846 } & & & & & $-0.432 * * *$ & $-0.421 * * *$ & & $-0.557 * * *$ & $-0.541 * * *$ \\
\hline & & & & & $(0.012)$ & $(0.012)$ & & $(0.016)$ & $(0.015)$ \\
\hline \multirow[t]{2}{*}{ ShareValue } & & & & & $0.000 * * *$ & $0.000 * * *$ & & $0.000^{* * * *}$ & $0.000 * * *$ \\
\hline & & & & & $(0.000)$ & $(0.000)$ & & $(0.000)$ & $(0.000)$ \\
\hline \multirow[t]{2}{*}{ ParMax } & & & & & $-1.628 * * *$ & $-1.639 * * *$ & & $-2.503 * * *$ & $-2.537 * * *$ \\
\hline & & & & & $(0.048)$ & $(0.048)$ & & $(0.075)$ & $(0.076)$ \\
\hline Constant & $1.081 * * *$ & $0.945^{* * * *}$ & $1.019 * * *$ & $0.960 * * *$ & 1.231 *** & $1.118 * * *$ & $1.112 * * *$ & $1.415^{* * * *}$ & $1.236 * * *$ \\
\hline & $(0.009)$ & $(0.008)$ & $(0.006)$ & $(0.007)$ & $(0.014)$ & $(0.012)$ & $(0.009)$ & $(0.020)$ & $(0.017)$ \\
\hline Observations & 28,951 & 28,951 & 28,951 & 28,951 & 28,043 & 28,043 & 20,061 & 19,782 & 19,782 \\
\hline R-squared & 0.005 & 0.008 & 0.001 & 0.008 & 0.059 & 0.060 & 0.000 & 0.097 & 0.101 \\
\hline
\end{tabular}


Notes: The dependent variable is the price/par ratio on the last day of trading of new railway schemes. $* * * \mathrm{p}<0.01, * * \mathrm{p}<0.05, * \mathrm{p}<0.1$ robust standard errors in parentheses. Inexperienced is a binary variable equal to one if the investor is skilled working class, unskilled working class or clergy; Women is a binary variable equal to one if the investor is a spinster or widow; Middle class is a binary variable equal to one if the investor is from the professional or white collar categories; Upper class is a binary variable equal to one if the investor is from the upper class; Business is a binary variable equal to one if the investor is a manufacturer or retailer; Merchant is a binary variable equal to one if the investor is a merchant; Politician is a binary variable equal to one if the investor is an MP; Finance is a binary variable equal to one if the investor is a banker, stockbroker or works in the financial sector; Legal is a binary variable equal to one if the investor is a member of the legal profession; Director is a binary variable equal to one if the investor is a railway director or secretary; Chairman is a binary variable equal to one if the investor is a railway chairman; Prov. Comm. is a binary variable equal to one if the investor is a member of the provisional committee; London is a binary variable equal to one if the investor resides there; Lancashire is a binary variable equal to one if the investor resides in that county; Local is a binary variable equal to one if the investor is from the county of the railway's termini; InvestBoth4546 is a binary variable equal to one if the investor subscribes to railways in both the 1845 and 1846 lists; PortfolioNum is the number of different railways that an investor subscribes to; PortfolioValue is the total value of railway investments made by an investor; Yearl846 is a binary variable equal to one if an investment is made in 1846; ShareValue is the value of the investment; ParMax is par value / nominal value i.e., fraction of capital which was called up. 
Table 6

Great Western Railway Shareholders, 1843-48

\begin{tabular}{|c|c|c|c|c|}
\hline & & $\begin{array}{l}1843 \\
(\%)\end{array}$ & $\begin{array}{l}1845 \\
(\%)\end{array}$ & $\begin{array}{l}1848 \\
(\%)\end{array}$ \\
\hline & Panel A: Socio-occupational status & & & \\
\hline & Clergymen & 0.6 & 0.7 & 0.6 \\
\hline \multirow[t]{2}{*}{ Inexperienced } & Skilled working class & 0.6 & 0.6 & 0.4 \\
\hline & Unskilled working class & 0.5 & 0.5 & 0.4 \\
\hline \multirow[t]{2}{*}{ Women } & Spinsters & 8.1 & 10.4 & 11.8 \\
\hline & Widows & 2.3 & 3.3 & 3.9 \\
\hline \multirow[t]{2}{*}{ Middle class } & Professionals & 3.3 & 3.4 & 3.0 \\
\hline & White collar & 5.2 & 5.9 & 5.7 \\
\hline \multirow{3}{*}{ Upper class } & Army \& navy officers & 1.5 & 2.3 & 2.6 \\
\hline & Gentlemen & 48.5 & 46.1 & 43.4 \\
\hline & Nobility & 0.5 & 0.7 & 0.5 \\
\hline Merchants & Merchants & 9.1 & 6.8 & 5.7 \\
\hline \multirow[t]{2}{*}{ Business } & Manufacturers & 3.5 & 2.9 & 2.6 \\
\hline & Retailers & 4.7 & 3.7 & 3.1 \\
\hline \multirow[t]{3}{*}{ Finance } & Bankers & 2.0 & 2.1 & 1.9 \\
\hline & Finance & 0.8 & 0.7 & 0.9 \\
\hline & Stockbrokers & 1.1 & 0.9 & 0.6 \\
\hline Political & Politicians & 0.4 & 0.5 & 0.4 \\
\hline Legal & Legal professionals & 2.5 & 2.7 & 2.9 \\
\hline \multirow[t]{9}{*}{ Other } & Agriculture & 1.2 & 1.2 & 1.0 \\
\hline & Unknown & 3.4 & 4.5 & 8.7 \\
\hline & Panel B: Location & & & \\
\hline & London & 24.1 & 25.3 & 24.9 \\
\hline & Gloucestershire & 17.8 & 15.3 & 14.3 \\
\hline & Lancashire & 16.1 & 14.6 & 12.1 \\
\hline & Somersetshire & 3.9 & 3.6 & 4.9 \\
\hline & Other & 38.0 & 41.2 & 43.8 \\
\hline & Total number of shareholders & 2,013 & 2,074 & 2,791 \\
\hline
\end{tabular}

Source: Authors' calculations based on Great Western Railway holders of $£ 100$ shares and $£ 20$ shares 1843, 1845 and 1848 (National Archives, RAIL 251/28, 29, 32, 50, 52 and 54). 


\section{Table 7}

GWR Investors during the Mania

\begin{tabular}{|c|c|c|c|c|c|}
\hline & $\begin{array}{l}\text { Long-term } \\
\text { investors } \\
(\%)\end{array}$ & $\begin{array}{l}\text { Gainers } \\
(\%)\end{array}$ & $\begin{array}{l}\text { Losers } \\
(\%)\end{array}$ & $\begin{array}{l}\text { Flippers } \\
(\%)\end{array}$ & $\begin{array}{l}\text { Total no. of } \\
\text { investors }\end{array}$ \\
\hline \multicolumn{6}{|c|}{ Panel A: Investor categories } \\
\hline Inexperienced & 22.9 & 27.1 & 34.3 & 15.7 & 70 \\
\hline Women & 14.6 & 19.2 & 55.5 & 10.7 & 625 \\
\hline Middle class & 22.6 & 21.8 & 40.3 & 15.3 & 385 \\
\hline Upper class & 17.8 & 28.3 & 41.0 & 12.8 & 2,203 \\
\hline Business & 26.2 & 34.2 & 31.3 & 8.4 & 275 \\
\hline Merchant & 24.0 & 36.2 & 28.3 & 11.5 & 304 \\
\hline Finance & 21.9 & 28.1 & 36.9 & 13.1 & 160 \\
\hline Legal & 14.6 & 23.8 & 48.5 & 13.1 & 130 \\
\hline Politician & 42.9 & 14.3 & 35.7 & 7.1 & 14 \\
\hline Other/Unknown & 8.6 & 15.6 & 61.8 & 14.0 & 385 \\
\hline \multicolumn{6}{|l|}{ Panel B: Location } \\
\hline London & 12.9 & 27.5 & 44.9 & 14.7 & 1,201 \\
\hline Gloucestershire & 25.9 & 26.4 & 38.3 & 9.3 & 621 \\
\hline Lancashire & 23.3 & 35.1 & 31.9 & 9.8 & 615 \\
\hline Somersetshire & 21.6 & 20.0 & 50.0 & 8.4 & 190 \\
\hline Other & 16.8 & 22.9 & 46.7 & 13.5 & 1,924 \\
\hline Total no. investors & 824 & 1,189 & 1,967 & 571 & 4,551 \\
\hline
\end{tabular}

Source: Authors' calculations based on Great Western Railway holders of $£ 100$ shares and $£ 20$ shares in Feb. 1843, Feb. 1845 and Feb. 1848 (National Archives, RAIL 251/28, 29, 32, 50, 52 and 54).

Notes: Long-term investors are those who held shares in Feb. 1843 and were still shareholders in Feb. 1848. Gainers are those who held shares in 1843, but were not holding them in 1848. Losers are those who were not holding shares in 1843, but were shareholders by 1848. Flippers are those who owned shares in 1845, but not in 1843 or 1848 . Inexperienced refers to an investor who is skilled working class, unskilled working class or clergy; Women refers to an investor who is a spinster or widow; Middle class refers to an investor who is from the professional or white collar categories; Upper class refers to an investor who is from the upper class; Director refers to an investor who is a director, secretary or chairman of an established railway company; Business refers to an investor who is a manufacturer or retailer; Merchant refers to an investor who is a merchant; Politician refers to an investor who is an MP; Finance refers to an investor who is a banker, stockbroker or works in the financial sector; Legal refers to an investor who is a member of the legal profession; London, Gloucestershire, Lancashire and Somersetshire refers to the location of an investor. 
Table 8

Multinominal Logit Regressions Showing which Categories of GWR Investors Were More Likely to be Losers, Long-term Investors, or Flippers, rather than Gainers

\begin{tabular}{|c|c|c|c|c|}
\hline & (1) & (2) & (3) & (4) \\
\hline & Gainers & Losers & Long-term & Flippers \\
\hline \multicolumn{5}{|l|}{ Panel A: Less experienced } \\
\hline Inexperienced & & $\begin{array}{l}-0.415 \\
(0.316)\end{array}$ & $\begin{array}{l}0.159 \\
(0.354)\end{array}$ & $\begin{array}{l}0.134 \\
(0.398)\end{array}$ \\
\hline Women & & $\begin{array}{l}0.413 * * * \\
(0.129)\end{array}$ & $\begin{array}{l}0.110 \\
(0.167)\end{array}$ & $\begin{array}{l}0.085 \\
(0.185)\end{array}$ \\
\hline Middle class & & $\begin{array}{l}-0.061 \\
(0.156)\end{array}$ & $\begin{array}{l}0.392 * * \\
(0.178)\end{array}$ & $\begin{array}{l}0.278 \\
(0.199)\end{array}$ \\
\hline Upper class & & $\begin{array}{l}-0.254 * * * \\
(0.090)\end{array}$ & $\begin{array}{l}-0.023 \\
(0.109)\end{array}$ & $\begin{array}{l}-0.161 \\
(0.126)\end{array}$ \\
\hline Director & & $\begin{array}{l}-0.542 \\
(0.376)\end{array}$ & $\begin{array}{l}0.209 \\
(0.328)\end{array}$ & $\begin{array}{l}-0.925 \\
(0.629)\end{array}$ \\
\hline Chairman & & $\begin{array}{l}-14.400 * * * \\
(0.387)\end{array}$ & $\begin{array}{l}-0.454 \\
(0.713)\end{array}$ & $\begin{array}{l}-14.431 * * * \\
(0.421)\end{array}$ \\
\hline London & & $\begin{array}{l}0.237^{*} \\
(0.127)\end{array}$ & $\begin{array}{l}-0.718^{* * * *} \\
(0.150)\end{array}$ & $\begin{array}{l}0.479 * * * \\
(0.182)\end{array}$ \\
\hline Lancashire & & $\begin{array}{l}-0.800 * * * \\
(0.118)\end{array}$ & $\begin{array}{l}-0.139 \\
(0.131)\end{array}$ & $\begin{array}{l}-0.696 * * * \\
(0.168)\end{array}$ \\
\hline Local & & $\begin{array}{l}-0.394 * * * \\
(0.118)\end{array}$ & $\begin{array}{l}0.262 * * \\
(0.133)\end{array}$ & $\begin{array}{l}-0.487 * * * \\
(0.172)\end{array}$ \\
\hline GWRandNew & & $\begin{array}{l}-0.544 * * * \\
(0.101)\end{array}$ & $\begin{array}{l}0.100 \\
(0.110)\end{array}$ & $\begin{array}{l}-0.426^{* * * *} \\
(0.140)\end{array}$ \\
\hline ShareValue & & $\begin{array}{l}-0.000 \\
(0.000)\end{array}$ & $\begin{array}{l}0.000 \\
(0.000)\end{array}$ & $\begin{array}{l}0.000 \\
(0.000)\end{array}$ \\
\hline Constant & & $\begin{array}{l}0.923 * * * \\
(0.091)\end{array}$ & $\begin{array}{l}-0.358^{* * * *} \\
(0.112)\end{array}$ & $\begin{array}{l}-0.459 * * * \\
(0.124)\end{array}$ \\
\hline $\begin{array}{l}\text { Observations } \\
\text { Panel B: More experienced }\end{array}$ & 4,551 & 4,551 & 4,551 & 4,551 \\
\hline Business & & $\begin{array}{l}-0.633 * * * \\
(0.160)\end{array}$ & $\begin{array}{l}-0.010 \\
(0.169)\end{array}$ & $\begin{array}{l}-0.638 * * * \\
(0.244)\end{array}$ \\
\hline Merchant & & $\begin{array}{l}-0.499 * * * \\
(0.160)\end{array}$ & $\begin{array}{l}-0.092 \\
(0.169)\end{array}$ & $\begin{array}{l}-0.143 \\
(0.213)\end{array}$ \\
\hline Finance & & $\begin{array}{l}0.024 \\
(0.212)\end{array}$ & $\begin{array}{l}0.064 \\
(0.241)\end{array}$ & $\begin{array}{l}0.219 \\
(0.282)\end{array}$ \\
\hline Politician & & $\begin{array}{l}1.136 \\
(0.846)\end{array}$ & $\begin{array}{l}1.683 * \\
(0.863)\end{array}$ & $\begin{array}{l}0.725 \\
(1.248)\end{array}$ \\
\hline Legal & & $\begin{array}{l}0.356 \\
(0.231)\end{array}$ & $\begin{array}{l}-0.095 \\
(0.303)\end{array}$ & $\begin{array}{l}0.228 \\
(0.315)\end{array}$ \\
\hline Director & & $\begin{array}{l}-0.629 \\
(0.384)\end{array}$ & $\begin{array}{l}0.158 \\
(0.335)\end{array}$ & $\begin{array}{l}-0.978 \\
(0.632)\end{array}$ \\
\hline Chairman & & $\begin{array}{l}-15.867 * * * \\
(0.536)\end{array}$ & $\begin{array}{l}-0.905 \\
(0.782)\end{array}$ & $\begin{array}{l}-15.883 \text { *** } \\
(0.579)\end{array}$ \\
\hline London & & $\begin{array}{l}0.056 \\
(0.127)\end{array}$ & $\begin{array}{l}-0.751 * * * \\
(0.150)\end{array}$ & $\begin{array}{l}0.346^{*} \\
(0.182)\end{array}$ \\
\hline Lancashire & & $\begin{array}{l}-0.689 * * * \\
(0.119)\end{array}$ & $\begin{array}{l}-0.142 \\
(0.134)\end{array}$ & $\begin{array}{l}-0.688^{* * * *} \\
(0.169)\end{array}$ \\
\hline Local & & $\begin{array}{l}-0.282 * * \\
(0.119)\end{array}$ & $\begin{array}{l}0.256 * \\
(0.133)\end{array}$ & $\begin{array}{l}-0.418^{* * *} \\
(0.172)\end{array}$ \\
\hline GWRandNew & & $\begin{array}{l}-0.502 * * * \\
(0.103)\end{array}$ & $\begin{array}{l}0.105 \\
(0.115)\end{array}$ & $\begin{array}{l}-0.402 * * * \\
(0.146)\end{array}$ \\
\hline ShareValue & & $\begin{array}{l}-0.000 * * \\
(0.000)\end{array}$ & $\begin{array}{l}0.000 \\
(0.000)\end{array}$ & $\begin{array}{l}0.000 \\
(0.000)\end{array}$ \\
\hline Constant & & $\begin{array}{l}0.899 * * * \\
(0.061)\end{array}$ & $\begin{array}{l}-0.299 * * * \\
(0.076)\end{array}$ & $\begin{array}{l}-0.458^{* * * *} \\
(0.081)\end{array}$ \\
\hline Observations & 4,551 & 4,551 & 4,551 & 4,551 \\
\hline
\end{tabular}


Notes: $* * * \mathrm{p}<0.01, * * \mathrm{p}<0.05, * \mathrm{p}<0.1$ robust standard errors in parentheses. Inexperienced is a binary variable equal to one if the investor is skilled working class, unskilled working class or clergy; Women is a binary variable equal to one if the investor is a spinster or widow; Middle class is a binary variable equal to one if the investor is from the professional or white collar categories; Upper class is a binary variable equal to one if the investor is from the upper class; Director is a binary variable equal to one if the investor is a director, secretary or chairman of an established railway company; Business is a binary variable equal to one if the investor is a manufacturer or retailer; Merchant is a binary variable equal to one if the investor is a merchant; Politician is a binary variable equal to one if the investor is an MP; Finance is a binary variable equal to one if the investor is a banker, stockbroker or works in the financial sector; Legal is a binary variable equal to one if the investor is a member of the legal profession; London is a binary variable equal to one if the investor resides there; Lancashire is a binary variable equal to one if the investor resides in that county; Local is a binary variable equal to one if the investor lived in London or Gloucestershire; GWRandNew is a binary variable equal to one if the investor also subscribed to a new railway during the Mania; ShareValue is the value of the investor's total investment in the Great Western Railway; Long-term investors are those who held shares in Feb. 1843 and were still shareholders in Feb. 1848. Gainers are those who held shares in 1843, but were not holding them in 1848. Losers are those who were not holding shares in 1843, but were shareholders by 1848. Flippers are those who owned shares in 1845, but not in 1843 or 1848. Pseudo-R2 for Panel A is 0.022 , for Panel B is 0.023 . 
Panel A: Weekly indices of all railway shares, and Great Western Railway shares, 1843-50

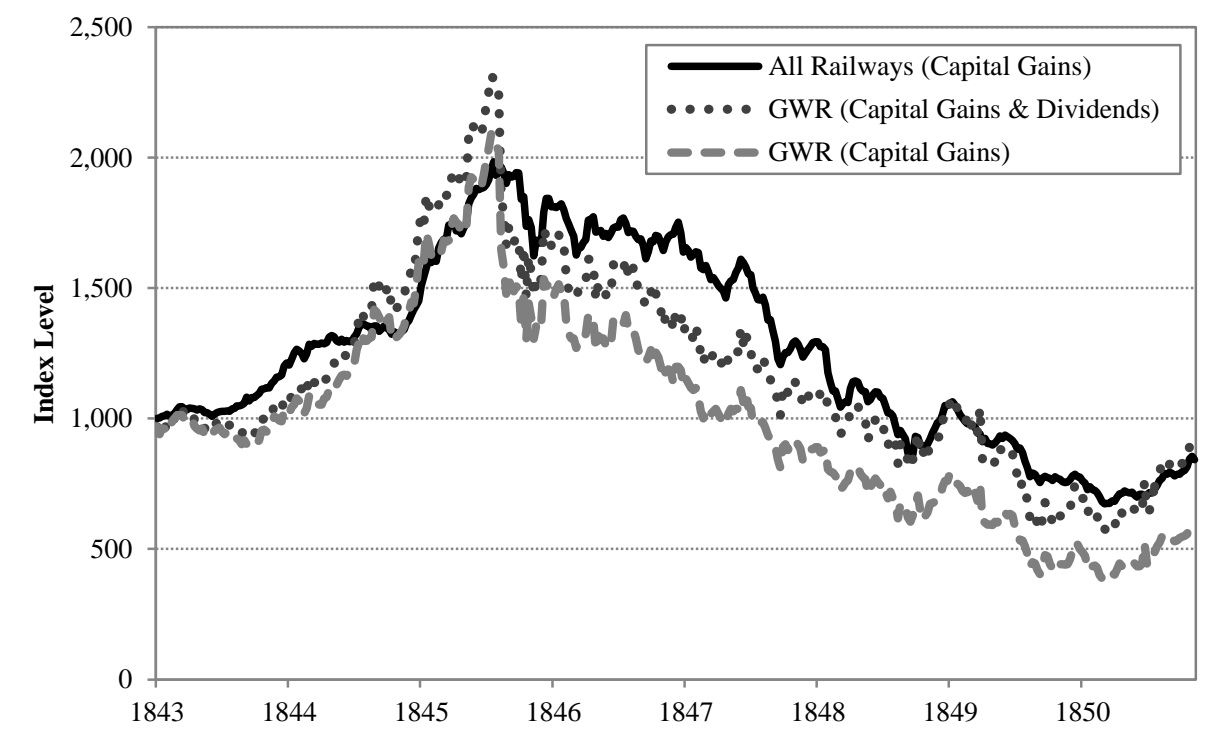

Panel B: Weekly indices of shares of established and new railway companies, 1843-50

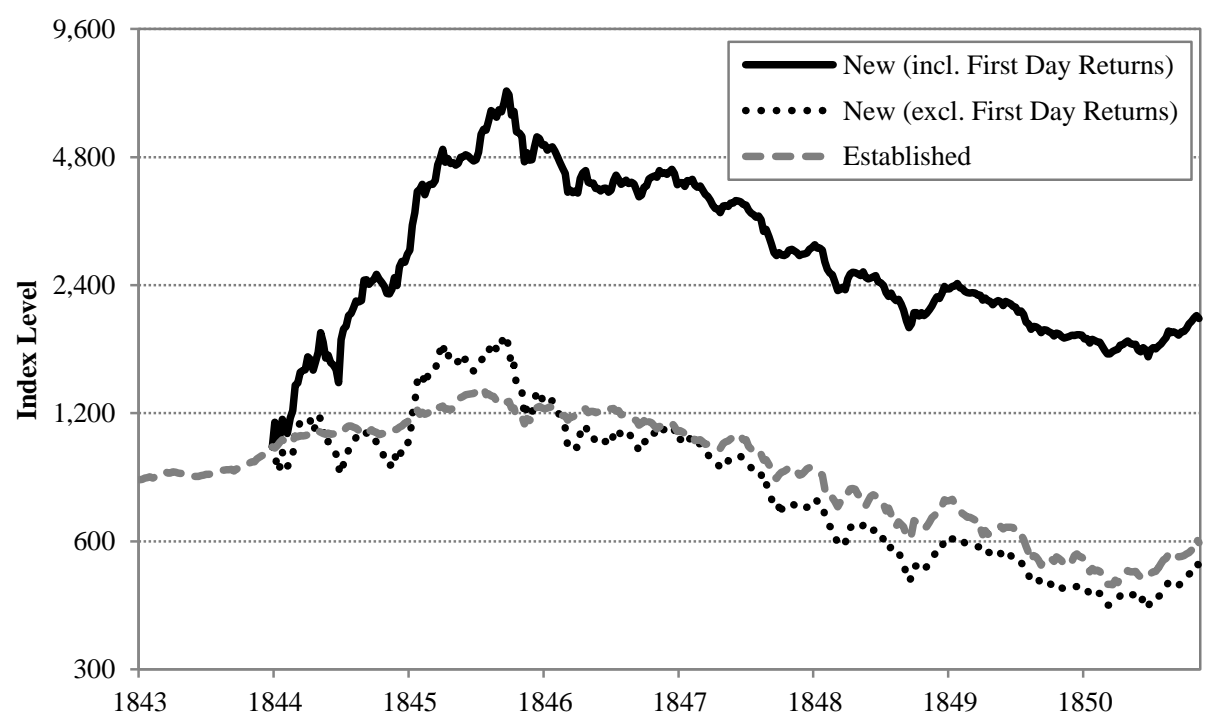

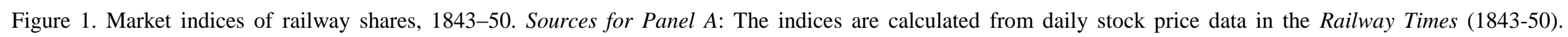
Dividend rates for the Great Western Railway were obtained from the Course of the Exchange.

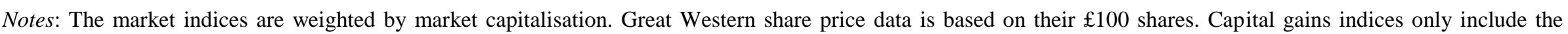

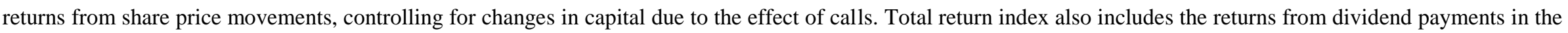
week that they changed, according to the Course of the Exchange.

Sources for Panel B: The indices are calculated from daily stock price data in the Railway Times (1843-50).

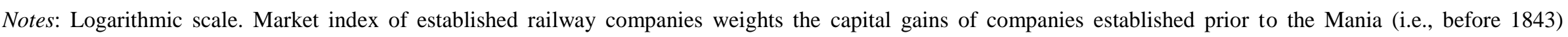

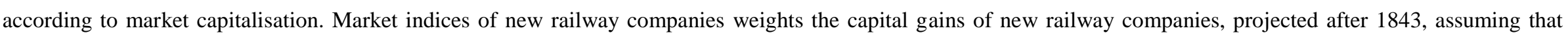

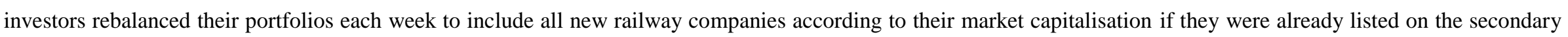

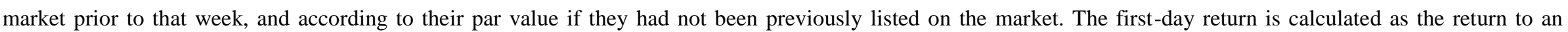

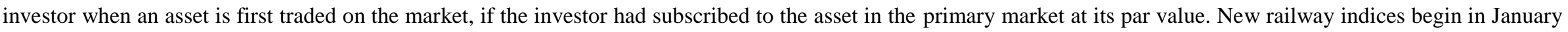
1844 when the first new railway company was listed on the market. All indices have a base of 1,000 in January 1844. 


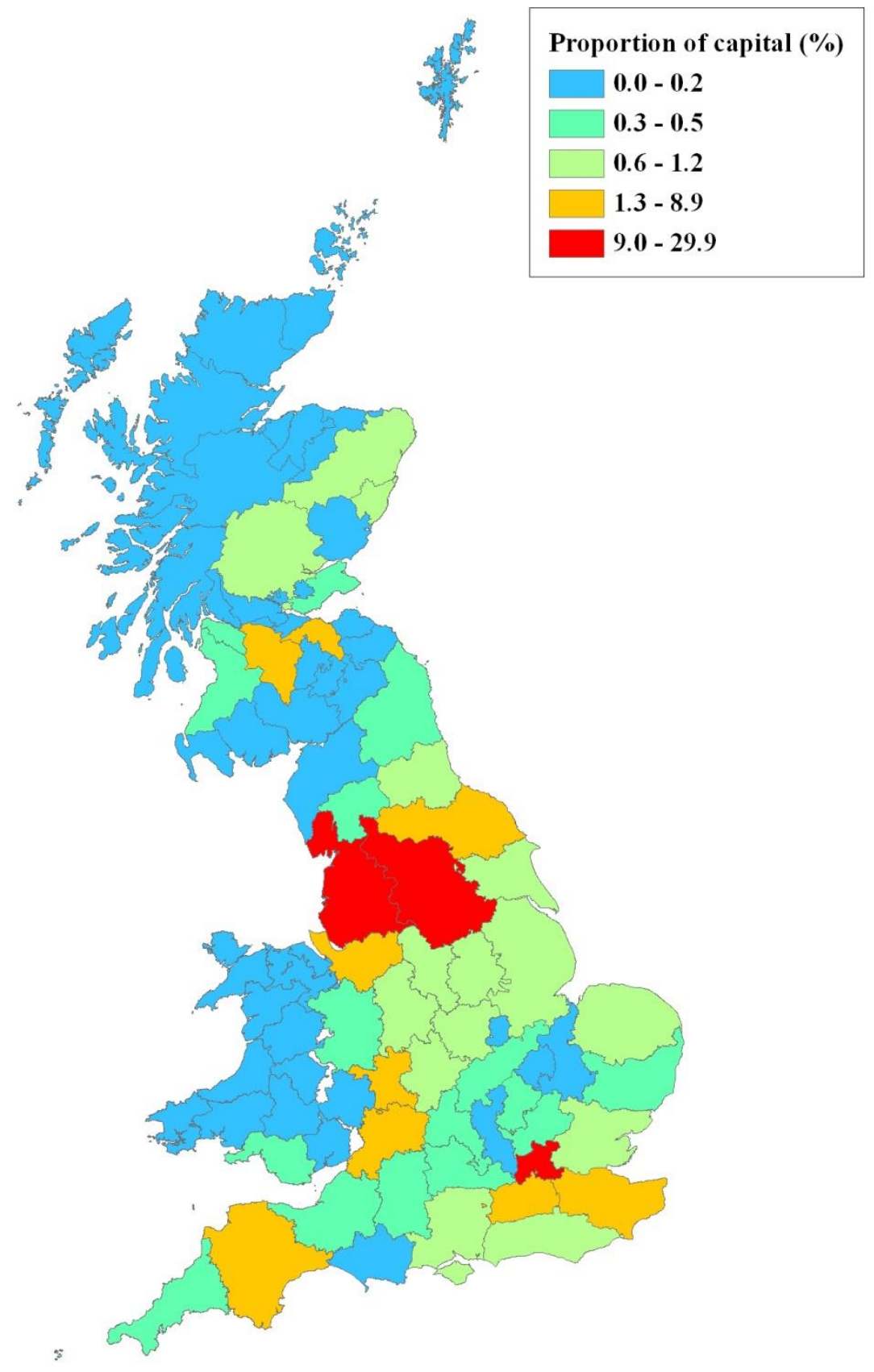

Figure 2. Geographical sources of investment during the Mania. Sources: Authors' calculations based on Return of Railway Subscribers, (P.P. 1845, XL), Return of Railway Subscribers, (P.P. 1846, XXXVIII). 